\title{
$J(\Theta)$
}

Received: 13.05 .2019

Accepted: 09.06.2019

Published: 24.06 .2019

JOTS, 3/2, 2019: 471-501

\section{Orhun Yazıtlarındaki Er- Bar- İkilemesi Üzerine}

\section{On the Reduplication är- bar- in the Orkhun Inscriptions}

\author{
Erdem UçAR \\ Prague/Czech Republic \\ E-mail: merdemu@gmail.com
}

There are still problems with translations the Orkhun inscriptions. Detailed explanations should be made on each word for correct understanding of the sentences in the inscriptions. The reduplication är- bar- is found in four places: 1. Köl Tigin East 23 = Bilgä Qayan East 19 (twice), 2. Köl Tigin North 1 and 3. Bilgä Qayan East 29. The four reproductions, which provide a copy of the inscriptions, have allied with the signs in the reduplication. Therefore, there is no difference in the reading of the reduplication. The article lists the previous interpretations for the reduplication. After the interpretation proposals were analysed, the meaning of the reduplication in question were re-evaluated.

Key Words: Köl Tigin inscription, Bilgä Qayan inscription, är- bar-, barım, barq, reduplication. 


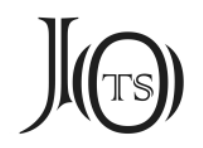

Köl Tigin ve Bilge Kagan yazıtlarında geçen er- bar-ikilemesinin anlamlandırılmasında bir sorun olduğundan şüphelenmiş ve önerilen teklifleri yeterince tatmin edici bulmamıştım. İkileme hakkındaki anlamlandırma tekliflerinin çoğunun bağlam esaslı olması ve tekliflerdeki filolojik gerekçelerin azlığı beni böyle düşünmeye sevk etmişti. Buradan hareketle er- bar-ikilemesinin geçtiği pasajların tekrar değerlendirilmesinin faydalı olabileceğini düşündüm.

Orhun yazıtlarında er-bar-ikilemesi toplam dört yerde geçmektedir:

1. (e)rm(i)ş b(a)rm(1)ş : (e)dgü (é)l(i)ye : k(e)ntü y(a)y(1)lt(1)g (KT D23 = BK D19).

2. köl tig(i)n : yéti ot(u)z: y(a)ş(1)ya :k(a)rluk : bod(u)n : (e)rür b(a)rur : (e)rkli : y(a)g1 bolt1 (KT K1).

3. ot(u)z (a)rtukı : bir : $y(a) s ̧(1) m a: k(a) r l u k:$ bod(u)n : buns $(u) z(e)$ rür : b(a)rur : (e)rkli : y(a)g1 bolt1 (BK D28-29).

Yazıtlar hakkında yayımlanan daha önceki makalelerimde yaptığım gibi ikilemenin yer aldığı cümlelerin şimdiye kadarki çalışmalarda nasıl anlamland1rıldığını kronolojik olarak listeleyerek karşılaştırmalı bir tablo sunmak istiyorum:

\begin{tabular}{|c|c|c|c|}
\hline Neşir & KT D23 = BK D19 & KT K1 & BK D28-29 \\
\hline Radloff 1895 & $\begin{array}{l}\text { ermiş barmış edgü } \\
\text { eline kendü yanıltın } \\
\text { "İlerleme içinde olan } \\
\text { iyi boyuna (beyine) } \\
\text { karşı hata yaptın". } \\
\text { (14-15,54-55) }\end{array}$ & $\begin{array}{l}\text { kül tegin yeti otuz yaşına karluk bu- } \\
\text { dun erür barur erkli yagı boldı "Kül } \\
\text { Tegin otuz yedi yaşındayken, göç } \\
\text { eden Karluk halkı bize düşman } \\
\text { oldu". (24-25) }\end{array}$ & $\begin{array}{l}\text { otuz artukı bir ya- } \\
\text { şıma karluk budun } \\
\text { buysaz erür barur } \\
\text { erkli yagı boltı "Otuz } \\
\text { bir yaşımda Karluk } \\
\text { halkı zengin ol- } \\
\text { duğu için bize düş- } \\
\text { man olmuştu". } \\
\text { (61); otuz artukı bir } \\
\text { yaşıma karlukbudun } \\
\text { buysı erür barur } \\
\text { erikli yagı boltı } \\
\text { "Otuz bir yaşım- } \\
\text { dayken Karluk } \\
\text { halkı engelsiz bir } \\
\text { şekilde özgürce ya- }\end{array}$ \\
\hline
\end{tabular}




\begin{tabular}{|c|c|c|c|}
\hline & & & $\begin{array}{l}\text { şarken bize düş- } \\
\text { man oldu" (190- } \\
\text { 191). }\end{array}$ \\
\hline $\begin{array}{l}\text { Thomsen } \\
\text { [1896] } 2002\end{array}$ & $\begin{array}{l}(e) r m(i) s ̧ \text { b(a)rm(l)ş : } \\
(e) d g u ̈(i) l(i) \eta e: k(e) n t u ̈ \\
y(a) \eta(() l t(1) g \text { “Özgürce } \\
\text { yaşamış olan iyi hal- } \\
\text { kına (devletine) karşı } \\
\text { gevşeklik gösteren } \\
\text { sensin". (142-143) }\end{array}$ & $\begin{array}{l}\text { kül tig(i)n : yéti ot }(u)_{z}: y(a) s ̧(1) \eta a: \\
\text { k(a)rluk : bod(u)n : (e)rür b(a)rur : } \\
\text { (e)rkli : } y(a) g ı \text { boltı "Kül Tegin otuz } \\
\text { yedi yaşında iken, Karluk halkı öz- } \\
\text { gür yaşayan cesur bir düşman } \\
\text { oldu" (154-155). }\end{array}$ & 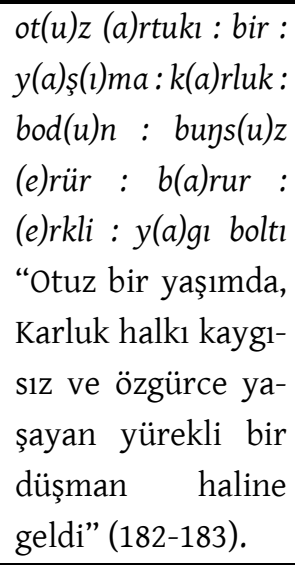 \\
\hline Bang 1896 & $\begin{array}{l}\text { ermiş barmış edgü } \\
\text { eline kendü yayıltıg } \\
\text { "Olmuş ve değişim } \\
\text { içinde olan iyi birli- } \\
\text { ğine karşı kötülük } \\
\text { yaptın". }(344,354)\end{array}$ & - & - \\
\hline Radloff 1897 & $\begin{array}{l}\text { ermiş barmış edgü } \\
\text { elige kendü yapıltın } \\
\text { "Olan ve ilerleme } \\
\text { içindeki iyi boyuna } \\
\text { karşı hata yaptın". } \\
\text { (136, dip. 3) }\end{array}$ & $\begin{array}{l}\text { kül tegin yeti otuz yaşııa karluk bu- } \\
\text { dun erür barur erkli yagı boldı "Kül } \\
\text { Tegin otuz yedi yaşındayken, ba- } \\
\text { ğımsızlığı için (yine) Karluk halkı } \\
\text { (bize karşı) düşman oldu”. (143) }\end{array}$ & $\begin{array}{l}\text { otuz artukı bir ya- } \\
\text { şıma karluk budun } \\
\text { buysuz erür barur } \\
\text { erikli yagı boltı } \\
\text { "Otuz bir yaşımda } \\
\text { Karluk halkı sınır- } \\
\text { sız bağımsızlığı ne- } \\
\text { deniyle bize düş- } \\
\text { man oldu". (140) }\end{array}$ \\
\hline Bang 1898 & - & $\begin{array}{l}\text { "Kül Tegin yirmi yedi yaşınday- } \\
\text { ken, Karluk her hâlükârda perva- } \\
\text { sız bir düşman olmuştu". (52) }\end{array}$ & - \\
\hline Vambéry 1899 & $\begin{array}{l}\text { ermiş barmış edkü iline } \\
\text { kendü yayıltıg "Eski- } \\
\text { den beri iyi olan bo- } \\
\text { yuna karşı hata yap- } \\
\text { tın". (45) }\end{array}$ & $\begin{array}{l}\text { kültigin yiti otuz yaşıı a karluk budun } \\
\text { erür barı erikli yagı boldı "Kül Tegin } \\
\text { otuz yedi yaşındayken, Karluk } \\
\text { halkı yavaş yavaş düşman ol- } \\
\text { muştu". (59) }\end{array}$ & - \\
\hline $\begin{array}{l}\text { Melioranskiy } \\
1899\end{array}$ & $\begin{array}{l}\text { igidmiş bilge kaganımın } \\
\text { ermiş barmış edgü } \\
\text { elige kendü yayıltıg } \\
\text { "Kendin suçlusun, }\end{array}$ & $\begin{array}{l}\text { kül tegin yeti otuz yaşııa karluk bu- } \\
\text { dun erür barur erikli yagı boldı "Kül }\end{array}$ & - \\
\hline
\end{tabular}




\begin{tabular}{|c|c|c|c|}
\hline & $\begin{array}{l}\text { eski sadakatiniz ve } \\
\text { iyi kabile birliğiniz } \\
\text { münasebetiyle sizi } \\
\text { yücelten akıllı ka- } \\
\text { gana kötülük yap- } \\
\text { tın". (69) }\end{array}$ & $\begin{array}{l}\text { Tigin yirmi yedi yaşındayken Kar- } \\
\text { luk halkı davranışlarından ötürü } \\
\text { (bize) düşman oldu". (74) }\end{array}$ & \\
\hline Thomsen $1935^{1}$ & $\begin{array}{l}\text { "Hür ve müstakil } \\
\text { olan memleketine } \\
\text { karşı hainlik ve al- } \\
\text { çaklık eden sensin". } \\
(102)\end{array}$ & $\begin{array}{l}\text { "Kül tigin yirmi yedi yaşında iken } \\
\text { o vakit hür ve müstakil olan Qar- } \\
\text { luq bizimle hasm olup harbe } \\
\text { girdi". (105) }\end{array}$ & $\begin{array}{l}\text { "Otuz bir yaşımda } \\
\text { Qarluqlar gailesiz, } \\
\text { hür ve müstakilken } \\
\text { düşman oldular" } \\
(105)\end{array}$ \\
\hline Orkun 1936 & 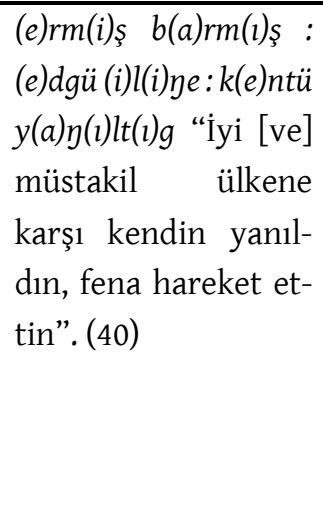 & $\begin{array}{l}\text { kül tig(i)n : yiti ot }(u)_{z}: y(a) s(1) \eta a \text { : } \\
\text { k(a)rluk : bud(u)n : (e)rür b(a)rur : } \\
(\text { (e)rkli : y(a)gı boldı "Kül tegin yirmi } \\
\text { yedi yaşında [iken] hür ve müsta- } \\
\text { kil olan Karluk kavmi düşman } \\
\text { oldu". (48) }\end{array}$ & $\begin{array}{l}\text { ot(u)z (a)rtukı : bir : } \\
y(a) s(l) m a: k(a) r l u k: \\
\text { bud(u)n : buys }(l) z \\
(e) r u ̈ r ~: ~ b(a) r u r ~: \\
(e) r k l i \text { : y(a)gı boldl } \\
\text { "Otuz bir yaşımda } \\
\text { kaygisı, hür ve } \\
\text { müstakil olan Kar- } \\
\text { luklar düşman ol- } \\
\text { dular" (62). }\end{array}$ \\
\hline Malov 1951 & $\begin{array}{l}\text { ermis barmıs edgü iline } \\
\text { kentü yayıltıg "Seni } \\
\text { yükselten iyi devle- } \\
\text { tine karşı hata yap- } \\
\text { tın". }(30,39)\end{array}$ & $\begin{array}{l}\text { kül tigin yiti otuz yaşııa karluk budun } \\
\text { erür barur erikli yagı boltı "Kül Tigin } \\
\text { yirmi yedi yaşındayken Karluk } \\
\text { halkı bağımsılığı ve özgrülüğün- } \\
\text { den dolayı (bize) düşman oldu". } \\
(32,41)\end{array}$ & - \\
\hline Tekin 1968 & $\begin{array}{l}\text { ermis barmıs edgü } \\
\text { éline kentü yayıltıg } \\
\text { "Sen hür ve bağımsız } \\
\text { olan kendi ülkene hi- } \\
\text { yanet ettin". (234, } \\
\text { 267) }\end{array}$ & $\begin{array}{l}\text { kül tigin yiti otuz yaşı̇a karluk bodun } \\
\text { erür barur erkli yagı boltı "Kül Tigin } \\
\text { yirmi yedi yaşındayken özgür ve } \\
\text { korkusuz davranmaya başlayan } \\
\text { Karluk düşman oldu". }(236,270)\end{array}$ & $\begin{array}{l}\text { otuz artukı bir ya- } \\
\text { şıma karluk budun } \\
\text { bunsız [er]ür barur } \\
\text { erkli yagı boltı "Otuz } \\
\text { bir yaşımda sıkınt1- } \\
\text { sız ve bağımsız } \\
\text { olan Karluk (bize } \\
\text { karşı düşman } \\
\text { oldu". }(244,276)\end{array}$ \\
\hline Ergin 1970 & $\begin{array}{l}\text { ermiş barmış edgü ilige } \\
\text { kentü yapıltıg "Hür ve }\end{array}$ & $\begin{array}{l}\text { kül tigin yiti otuz yaşıı a karluk budun } \\
\text { erür barur erkli yagı boldl "Kül Tigin }\end{array}$ & $\begin{array}{l}\text { otuz artukı bir ya- } \\
\text { şıma karluk budun }\end{array}$ \\
\hline
\end{tabular}

1 THOMSEN, en son hazırladığı Danca neşirde de cümleyi aynı şekilde tercüme etmiştir (Ross 1930: 867, $869,873)$. 


\begin{tabular}{|c|c|c|c|}
\hline & $\begin{array}{l}\text { müstakil iyi iline } \\
\text { karş1 kendin hata et- } \\
\text { tin". }(8,25,54,64)\end{array}$ & $\begin{array}{l}\text { yirmi yedi yaşına gelince Karluk } \\
\text { halkı hür ve müstakil iken düşman } \\
\text { oldu". }(12,57)\end{array}$ & $\begin{array}{l}\text { buysuz [er] ür barur } \\
\text { erkli yagı boldl } \\
\text { "Otuz bir yaşımda } \\
\text { Karluk milleti sı- } \\
\text { kıntısız, hür ve ser- } \\
\text { best iken, düşman } \\
\text { oldu". }(25,67)\end{array}$ \\
\hline Aydarov 1971 & $\begin{array}{l}\text { ermis barmıs edgü } \\
\text { eline kentü yayıltıg “... } \\
\text { güzel devletine karşı } \\
\text { sen kendin suç işle- } \\
\text { din”. (295) }\end{array}$ & $\begin{array}{l}\text { kül tigin yiti otuz yaşııa karlukbudun } \\
\text { erür barur erikli yagı boltı "Kül Tigin } \\
\text { yirmi yedi yaşındayken Karluk } \\
\text { halkı özgürlüğü ve bağımsızlığ1 } \\
\text { yüzünden (bize) düşman oldu". } \\
\text { (300) }\end{array}$ & $\begin{array}{l}\text { otuz artukı bir ya- } \\
\text { şıma karluk budun } \\
\text { buysı (er)ür barur } \\
\text { erikli yagı boltı } \\
\text { "Otuz bir yaşımda } \\
\text { Karluklar özgür- } \\
\text { lüğü ve bağımsız- } \\
\text { lı̆̆ı yüzünden bize } \\
\text { düşman oldu". } \\
(310)\end{array}$ \\
\hline Clauson 1972 & $\begin{array}{l}\text { ermiş barmış edgü } \\
\text { elipe kentü yayıltıg } \\
\text { "Bağımsız (?) iyi ül- } \\
\text { kene karşı kendin } \\
\text { hata yaptın". (194a) }\end{array}$ & $\begin{array}{l}\text { karluk bodun erür barur erikli yagı } \\
\text { boldı "Karluk halkı bağımsızmış } \\
\text { gibi davranarak düşman oldu". } \\
\text { (194a) }\end{array}$ & - \\
\hline $\begin{array}{c}\text { Abdurahmo- } \\
\text { nov-Rustamov } \\
1982\end{array}$ & $\begin{array}{l}\text { ermis barmıs edgü } \\
\text { eline kentü yayıltıg } \\
\text { "Harap olan, (elden } \\
\text { giden) iyi devletine, } \\
\text { kendin hata yaptın". } \\
\text { (106) }\end{array}$ & $\begin{array}{l}\text { kül tigin yiti otuz yaşı̨a karluk budun } \\
\text { erür barur erkeli yagı boldı "Kül Ti- } \\
\text { gin yirmi yedi yaşında Karluk halkı } \\
\text { yabancılaşıp gidince düşman } \\
\text { oldu". (110) }\end{array}$ & $\begin{array}{l}\text { otuz artukı bir ya- } \\
\text { şıma karluk bodun } \\
\text { buysı erür barur er- } \\
\text { keli yagı boldı "Otuz } \\
\text { bir yaşımda Karluk } \\
\text { halkı son derece } \\
\text { yabancılaşarak } \\
\text { düşman oldu". } \\
(128)\end{array}$ \\
\hline Tekin 1988 & 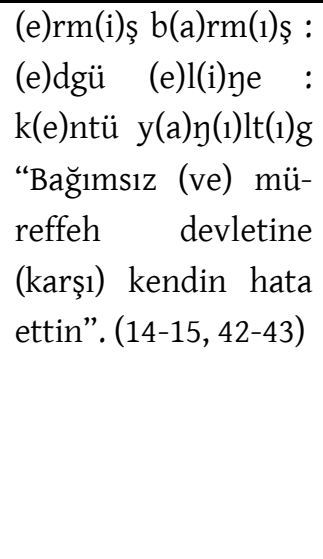 & $\begin{array}{l}\text { köl tig(i)n : yiti ot(u)z: y(a)ş(1)ya : } \\
\text { k(a)rluk : bod(u)n : (e)rür b(a)rur : } \\
\text { (e)rkli : y(a)g1 boltı "Kül Tigin } \\
\text { yirmi yedi yaşında (iken) Karluk } \\
\text { halkı (serbestçe) hareket eden } \\
\text { (bir) düşman oldu.". (20-21) }\end{array}$ & $\begin{array}{l}\text { ot(u)z (a)rtukı : bir } \\
: \quad y(a) s ̧(1) \text { ma : } \\
\text { k(a)rluk : bod(u)n : } \\
\text { buys(u)z (e)rür : } \\
\text { b(a)rur : (e)rkli : } \\
\text { y(a)gı boltı "Otuz } \\
\text { bir yaşımda Karluk } \\
\text { halkı bağımsızca } \\
\text { hareket eder (bir) } \\
\text { düşman oldu.". } \\
(46-47)\end{array}$ \\
\hline
\end{tabular}




\begin{tabular}{|c|c|c|c|}
\hline Şükürlü 1993 & $\begin{array}{l}\text { igidmiş bilge kaganı̇a } \\
\text { ermis barmıs edgü ilige } \\
\text { kentü yayıltıg "Güzel } \\
\text { ülke birliğine olan } \\
\text { sadakatin hatırına } \\
\text { seni yükselten be- } \\
\text { yine (karş1) alçaklık } \\
\text { yaptın". }(230,235)\end{array}$ & $\begin{array}{l}\text { kül-tigin yiti otuz yaşııa karluk bodun } \\
\text { erür barur erikli yagı boltı "Kül Tigin } \\
\text { yirmi yedi yaşındayken bağımsız } \\
\text { olmadı̆̆ından, tâbi olduğundan } \\
\text { Karluk halkı bize düşman oldu". } \\
(231,237)\end{array}$ & $\begin{array}{l}\text { otuz artukı bir ya- } \\
\text { şıma karluk bodun } \\
\text { buysuz [er]ür barur } \\
\text { erikli yagı boltı } \\
\text { "Otuz bir yaşımda } \\
\text { Karluk halkı sıkın- } \\
\text { tısı, hür ve göçebe } \\
\text { iken bize düşman } \\
\text { oldu". }(260,264)\end{array}$ \\
\hline $\begin{array}{l}\text { Sidikov-Konko- } \\
\text { bayev } 2001\end{array}$ & $\begin{array}{l}\text { ermis barmıs edgü ilipe } \\
\text { kentü yayıltıg "Gerçek } \\
\text { ülkene karşı olup } \\
\text { kendin hata ettin ve } \\
\text { düşman getirdin". } \\
(58,69)\end{array}$ & $\begin{array}{l}\text { kül tigin yiti otuz yaşııa karluk budun } \\
\text { erür barur erikli yagı boltı "Kül Tigin } \\
\text { yirmi yedi yaşındayken Karluk } \\
\text { halkı gelip- gitmekten (bağımsız- } \\
\text { lıktan) faydalanıp düşman oldu". } \\
(61,72)\end{array}$ & $\begin{array}{l}\text { otuz artukı bir ya- } \\
\text { şıma karluk budun } \\
\text { buysuz [er]ür barır } \\
\text { erikli yagı boltı } \\
\text { "Otuz bir yaşımda } \\
\text { Karluk halkı sıkın- } \\
\text { tısız, hür olarak gö- } \\
\text { çerken bize düş- } \\
\text { man oldu". (105, } \\
\text { 111) }\end{array}$ \\
\hline $\begin{array}{l}\text { Amanjolov } \\
2003\end{array}$ & $\begin{array}{l}(e) r m(i) \text { s b(a)rm(l)s } \\
(e) d g \ddot{u}(e) l(i) \text { ye } k(e) n t u ̈ \\
y(a) \eta(i) l t(1) g \text { "Seni yü- } \\
\text { celtip sana vefalı } \\
\text { olan boyuna karş1 } \\
\text { kendin suç işledin". } \\
(157,165)\end{array}$ & $\begin{array}{l}\text { kül tig(i)n yiti ot }(u)_{z} \text { y }(a)_{s}(1) \text { ya } \\
\text { k(a)rluk bod(u)n (e)rür b(a)rur (e)rkli } \\
y(a) g ı \text { boldı "Kül Tigin yirmi yedi } \\
\text { yaşındayken Karluk halkı özgürlü- } \\
\text { ğünü ve bağımsızlığını kazanarak } \\
\text { (bize) düşman oldu". }(158,168)\end{array}$ & - \\
\hline Erdal 2004 & - & $\begin{array}{l}\text { karlok bodun erür <buysuz> barur } \\
\text { erkli yagı boltı "Karluk halkı kaygi- } \\
\text { stzca yaşarken (beklenmedik şe- } \\
\text { kilde) düşman oldu". (476) }\end{array}$ & $\begin{array}{l}\text { karlok bodun buysuz } \\
\text { erür barur erkli yagl } \\
\text { boltı "Karluk halkı } \\
\text { kaygisızca yaşar- } \\
\text { ken (beklenmedik } \\
\text { şekilde) düşman } \\
\text { oldu". (476) }\end{array}$ \\
\hline Sodikov 2004 & $\begin{array}{l}\text { igidmis bilge kaganına } \\
\text { ermis barmıs edgü } \\
\text { eline kentü yayıltıg } \\
\text { "Terbiye eden bilge } \\
\text { hakanına, harap } \\
\text { olan, giden iyi devle- } \\
\text { tine, sen kendin hata } \\
\text { yaptın". }(87,94)\end{array}$ & $\begin{array}{l}\text { kül tigin yiti otuz yaşıı a karluk bodun } \\
\text { erür barur erkeli yagı boltı "Kül Tigin } \\
\text { yirmi yedi yaşında Karluk halkı ya- } \\
\text { bancılaşıp (arada ihtilaf çııı) düş- } \\
\text { man oldu”. }(101,110)\end{array}$ & $\begin{array}{l}\text { otuz artukı bir ya- } \\
\text { şıma karluk bodun } \\
\text { bunsız (er)ür barur } \\
\text { erkeli yagı boltı } \\
\text { "Otuz bir yaşımda } \\
\text { Karluk halkı son } \\
\text { derece yabancıla- } \\
\text { şı gidince düşman } \\
\text { oldu". }(113,117)\end{array}$ \\
\hline
\end{tabular}




\begin{tabular}{|c|c|c|c|}
\hline Bazılhan 2005 & $\begin{array}{l}\text { ermiş barmış edgü Elì } \\
\text { kentü yayıltıg "Kand1- } \\
\text { rıldığın, iktidarlı ka- } \\
\text { ğanın var idi. İyi dev- } \\
\text { letin kendi yanıldı". } \\
(69,90)\end{array}$ & $\begin{array}{l}\text { kültegin yeti otuz yaşı̇a karluk bu- } \\
\text { dun erür barur erikli yagı boltı "Kül } \\
\text { Tegin yirmi yedi yaşında Karlukla- } \\
\text { rın hepsi (halkı) takip edip gelip } \\
\text { bağımsız bir düşman oldu". (74) }\end{array}$ & $\begin{array}{l}\text { otuz artukı bir ya- } \\
\text { şıma karluk budun } \\
\text { buysız (er)ür barur } \\
\text { erikli yagı boltı } \\
\text { "Otuz bir yaşımda } \\
\text { Karlukların hepsi } \\
\text { (halkı) sıkıntısızta- } \\
\text { kip edip bağımsız } \\
\text { bir düşman oldu.". } \\
\text { (93) }\end{array}$ \\
\hline Geng 2005 & $\begin{array}{l}\text { ermiş barmış edgü } \\
\text { eline kentï yayıltıg } \\
\text { "Hür ve başına buy- } \\
\text { ruk güzel ülkene } \\
\text { hata yaptın". (127, } \\
\text { 156) }\end{array}$ & $\begin{array}{l}\text { kül tigin yiti otuz yaşııa karluk bodun } \\
\text { erür barur erikli yagı boltı "Kül Tigin } \\
\text { yirmi yedi yaşında Karluk halkı } \\
\text { hür ve başına buyruk iken düşman } \\
\text { oldu". (132) }\end{array}$ & $\begin{array}{l}\text { otuz artukı bir ya- } \\
\text { şıma karluk bodun } \\
\text { buysuz (er)ür barur } \\
\text { erikli yagı boltı } \\
\text { "Otuz bir yaşımda } \\
\text { Karluk halkı sıkın- } \\
\text { tısız olarak hür ve } \\
\text { başına buyrukken } \\
\text { bize düşman oldu". } \\
(160)\end{array}$ \\
\hline Tuguşeva 2008 & $\begin{array}{l}(e) r m(i)_{S ̧} \quad b(a) r m(l) s ̧ \\
(e) d g u ̈(e) l(i) \text { ge } k(e) n t u ̈ \\
y(a) \eta(l) l t(l) g \text { "Seni yü- } \\
\text { celtip sana vefalı } \\
\text { olan boyuna karşı } \\
\text { suç işledin". }(30,42)\end{array}$ & $\begin{array}{l}\text { kül tég(i)n yéti ot(u)z y(a)ş(l)ya } \\
\text { k(a)rluk bod(u)n (e)rür b(a)rur (e)rkli } \\
\text { y(a)gı boltı "Kül Tigin yirmi yedi ya- } \\
\text { şındayken Karluk halkı özgür ve } \\
\text { serbestken (bize) düşman oldu" } \\
(32,46) \text {. }\end{array}$ & 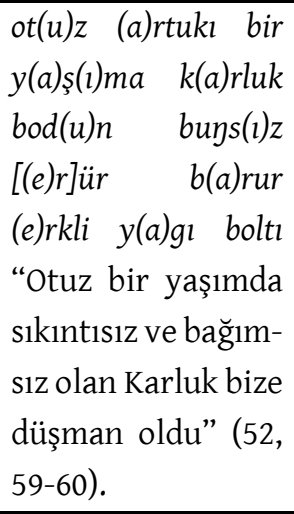 \\
\hline Recebli 2009 & $\begin{array}{l}\text { ermis barmıs edgü ilipe } \\
\text { kentü yayıltıg "Hoş } \\
\text { manzaralı güzel ül- } \\
\text { kene sen kendin hata } \\
\text { ettin". }(294,302)\end{array}$ & $\begin{array}{l}\text { kül tigin yeti otuz yaşına karluk bu- } \\
\text { dun erür barur erikli yagı boltı "Kül } \\
\text { Tigin yirmi yedi yaşındayken Kar- } \\
\text { luk halkı hür ve serbestken düş- } \\
\text { man oldu". }(296,304)\end{array}$ & $\begin{array}{l}\text { otuz artukl bir ya- } \\
\text { şıma karluk bodun } \\
\text { bunsız erür barur } \\
\text { erikli yagı boltı } \\
\text { "Otuz bir yaşı- } \\
\text { dayken Karluk } \\
\text { halkı kaygısız, hür } \\
\text { ve serbestken düş- } \\
\text { man olmuştu". } \\
(335,346)\end{array}$ \\
\hline Berta 2010 & $\begin{array}{l}\text { ermiş barmış edgü élin } \\
\text { kendü yayıltıg "[Sen] }\end{array}$ & $\begin{array}{l}\text { köl tégin yéti otuz yaşııa karluk bo- } \\
\text { dun erür barur erikli yagı boldl "Köl }\end{array}$ & $\begin{array}{l}\text { otuz artukl bir ya- } \\
\text { şıma karluk bodun }\end{array}$ \\
\hline
\end{tabular}




\begin{tabular}{|c|c|c|c|}
\hline & $\begin{array}{l}\text { bilge kağanınla imiş- } \\
\text { sin, [onunla birlikte] } \\
\text { gitmişsin. İyi elini } \\
\text { kendin bozdun". } \\
(154-155,195)\end{array}$ & $\begin{array}{l}\text { Tegin yirmi yedi yaşında iken, Kar- } \\
\text { luk bodunu başına buyruk bir düş- } \\
\text { man oldu". }(179,200)\end{array}$ & $\begin{array}{l}\text { buysuz erür barur } \\
\text { erikli yagı boldı } \\
\text { "Otuz bir yaşımda } \\
\text { Karluk bodunu [ar- } \\
\text { tık] -sıkıntısız- bir } \\
\text { düşman oldu". } \\
(166,197)\end{array}$ \\
\hline $\begin{array}{c}\text { Karcaubay } \\
2012\end{array}$ & $\begin{array}{l}\text { bilige kaganının ermis } \\
\text { barmıs edgü eline } \\
\text { kendü yayıltıg "Bağlı- } \\
\text { lığın için [seni] iyi } \\
\text { hale getiren bilgili } \\
\text { [bir] kağanın olma- } \\
\text { sına rağmen güzel } \\
\text { ülken [halkın] ken- } \\
\text { disi hata etti". (56, } \\
62 \text { ) }\end{array}$ & $\begin{array}{l}\text { kül-tigin yiti otuz yaşıı a karluk bodun } \\
\text { erür barur erkili yagı boltı "Kültegin } \\
\text { yirmi yedi yaşındayken Karluk } \\
\text { halkı, kendi davranışlarının nede- } \\
\text { niyle sonunda düşman oldu". (57, } \\
64 \text { ) }\end{array}$ & $\begin{array}{l}\text { otuz artukı bir ya- } \\
\text { şıma karluk bodun } \\
\text { bunsız [er]ür barur } \\
\text { erikli yagı boldl } \\
\text { "Otuz bir yaşım- } \\
\text { dayken Karluk } \\
\text { halkı ummadığ1- } \\
\text { mız yerden bir ta- } \\
\text { kip yapip bir yok } \\
\text { olup düşman ol- } \\
\text { muştu". }(96,103)\end{array}$ \\
\hline Ölmez 2012 & $\begin{array}{l}\text { ermiş barmış : edgü } \\
\text { éline : kentü : yayıltıg } \\
\text { "Kağanının refah ve } \\
\text { huzur içerisindeki } \\
\text { ülkesine karşı sen } \\
\text { kendin hata ettin". } \\
(83,96,126,140)\end{array}$ & $\begin{array}{l}\text { kül tégin : yéti otuz yaşına : karluk: } \\
\text { bodun : erür barur erkli : yagı boltı } \\
\text { "Yirmi yedi yaşında iken Karluk } \\
\text { halkı gelişip düşman oldu". }(87,99)\end{array}$ & $\begin{array}{l}\text { otuz: artukı: bir:ya- } \\
\text { şıma: karluk: bodun } \\
\text { : buysuz: [er]ür : ba- } \\
\text { rur: erkli : yagı boltı } \\
\text { "Otuz bir yaşım- } \\
\text { dayken Karluk } \\
\text { halkı refah içeri- } \\
\text { sinde bağımsız ha- } \\
\text { reket eder hale } \\
\text { geldi ve (bize) düş- } \\
\text { man oldu". (128, } \\
\text { 143) }\end{array}$ \\
\hline Ercilasun 2016 & $\begin{array}{l}\text { ermiş barmış edgü iline } \\
\text { kentü yayıltıg "Kal- } \\
\text { kınmış ve müreffeh, } \\
\text { güzel ülkene \{sen\}} \\
\text { kendin yanıldın". } \\
(520-521)\end{array}$ & $\begin{array}{l}\text { köl tigin yiti otuz yaşııła karluk bodun } \\
\text { erür barur erkli yagı boltı "Köl tigin } \\
\text { yirmi yedi yaşında iken Karluk } \\
\text { halkı, kalkınmış ve müreffeh ol- } \\
\text { duğu halde düşman oldu". (532- } \\
\text { 533) }\end{array}$ & $\begin{array}{l}\text { otuz artukı bir ya- } \\
\text { şıma karluk bodun } \\
\text { buysuz erür barur } \\
\text { erkli yagı boltı "Otuz } \\
\text { bir yaşımda iken } \\
\text { Karluk halkı, sıkın- } \\
\text { tısız, kalkınmış ve } \\
\text { müreffeh olduğu } \\
\text { halde düşman } \\
\text { oldu". (572-573) }\end{array}$ \\
\hline Aydın 2017 & $\begin{array}{l}\text { érmiş barmış edgü } \\
\text { éline kentü yayıltıg }\end{array}$ & $\begin{array}{l}\text { köl tégin yéti otuz yaşıı́ karlok bodun } \\
\text { erür barur erkli yagı boltı “Köl Tegin }\end{array}$ & $\begin{array}{l}\text { otuz artukı bir ya- } \\
\text { şıma karlok bodun }\end{array}$ \\
\hline
\end{tabular}




\section{$J(\Theta)$}

\begin{tabular}{|l||l||l|l||}
\hline \hline & $\begin{array}{l}\text { "Her tarafa ulaşmış } \\
\text { iyi (durumdaki) yur- } \\
\text { duna (karşı) sen ken- } \\
\text { din hata ettin". (58, } \\
\text { 86-87) }\end{array}$ & $\begin{array}{l}\text { yirmi yedi yaşında, Karluk halkı } \\
\text { gelip gider iken (durduk yere?) } \\
\text { düşman oldu". (64) }\end{array}$ & $\begin{array}{l}\text { bujsuz erür barur } \\
\text { erkli yagı boltı "Otuz } \\
\text { bir yaşımda Karluk } \\
\text { halkı sıkıntısızca } \\
\text { hareket eder hale } \\
\text { geldi, (bundan do- } \\
\text { layı) } \\
\text { oldü. (91) }\end{array}$ \\
\hline
\end{tabular}

İkileme hakkında daha önce nelerin söylendiğine kısaca temas etmek gerekirse, RADLOFF, erür barur erkli'nin 'varlığı ve ilerleyişi tamamen bağımsız' anlamında olabileceğini belirterek buysı'ın 'tasasız, kaygısız' anlamında olduğunu ifade etmiştir (1895: 236-238). THOMSEN, KT D23 = BK D19'daki er- bar-'in kelime kelime 'olmak gitmek' anlamında olduğunu, ama cümlede 'keyfine göre (göçebe olarak) yaşamak ve davranmak, özgürce yaşamak, özgürlüğün tadını çıarmak' anlamında olabileceğini söylemiş ve BK'deki kaganııa şeklinin kabul edilmesi gerektiğini ifade etmiştir (2002 [1896]: 222). THOMSEN, daha sonra neşrettiği Turcica'da er-bar- deyiminin 'istediği gibi yaşamak ve hareket etmek, istediğini yapmak, kendi kendisinin efendisi olmak, özgür ve bağımsız olmak' anlamında olabileceğini iddia etmiş ve deyimin olumlu bir anlama geldiğini belirtmiştir. Ayrıca, RADLOFF'un tercüme denemelerinin yanlış olduğunu ifade etmiştir (2002 [1916]: 378-379, dip. 3). BANG, ermiş barmış'ın 'her halükârda' anlamına gelen bir zarf olabileceğini tahmin etmiştir (1896: 345). VAMBÉRY, ermiş barmış'ın Osmanl1cadaki olmuş imiş ile aynı olabileceğini düşünmüştür (1896: 45). TEKin, KT D23'teki ermiş barmış' ' 'ilerlemiş, kalkınmış, bağımsız ve müreffeh' diye anlamlandırarak er-fiilinin 'erişmek, vasıl olmak' anlamındaki fiil olabileceğini düşünmüştür. Ona göre, 'gitmek, yürümek' anlamındaki fiillerin 'kalkınmak, kalkınmış ve ilerlemiş olmak' anlamına gelmesi ihtimal dâhilindedir. Ancak KT K1 ve BK D29'daki erür barur erkli'nin 'gelir gider olan', yani 'kendi başına buyruk olan, serbestçe karar verip hareket eden' anlamında olması gerektiğini iddia etmiştir (1988: 77, 84). ERDAL, KT K1 ve BK D29'da aynı olayların anlatılması nedeniyle buysuz erür barur'un 'kaygısızca yaşayan' ile tercüme edilebileceğini düşünür ve buysuz 'kayg1sız' ile buysuz erür barur'un 'kaygısızca yaşayan' ile denk olabileceğini tahmin etmiştir (2004: 476-477, dip. 651). TUGUŞEVA, er- bar- ikilemesinin 'dolaşmak, göç etmek', yani 'bağımsız, özgür' anlamında olabileceğini söylemiştir (2008: 60, dip. 


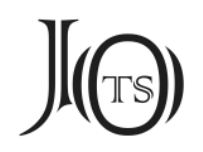

99). KARCAUBAY, KT D23’teki cümleyi “Bağlllığın için [seni] iyi hale getiren bilgili [bir] kağanın olmasına rağmen güzel ülken [halkın] kendisi hata etti” şeklinde tercüme etmiştir. Ayrıca, bar-fiilinin 'var olmak' anlamına gelebileceğini ve aynı anlamdaki er- fiilini pekiştirdiğini düşünmüştür (2012: 71). ŞiRiN, KT K1 ve BK D29'daki erür barur erkli'nin anlamı konusunda TEKiN'in teklifini kabul etmiştir (2015: 231, 286). Ayrıca, er- fiilinin 'olmak; var olmak; olgunlaşmak' karşıllı̆ıında değil, bu anlamlardan gelişen 'kalkınmak, müreffeh düzeye ulaşmak, ekonomik ve siyasal bağımsızlık içinde olmak' üst anlam katmanıyla kullanıldığına değinip yine bar- fiilinin çok katmanlı bir anlam yapısının olduğunu söylemiş ve fiilin 'zenginleşmek, kalkınmak, mamur duruma gelmek, müreffeh düzeye ulaşmak, ekonomik ve siyasal bağımsızlık içinde olmak, iyi bir yaşam sürmek' gibi anlamlarına dikkat çekmiştir (2016: 49, 62-63). ERCiLASUN, er- bar- ikilemesinin dört yerde de birlikte değerlendirilmesi gerektiğini, cümlenin tercümesinde erkli'nin dikkate alınmamasının yanlış olabileceğini ve erür barur'un yagı'nın sıfatı olarak kabul edilmemesi gerektiğini ifade etmiştir (2016: 637).

İkilemenin anlamını belirlemeden önce, ikilemenin geçtiği cümlelerdeki bazı soruların cevaplanması gerekmektedir. Sorular şunlardır:

\section{KT D23 = BK D19'daki ermiş barmış ikilemesinde yer alan $\{-\mathrm{mX}$ ş\} eki- nin okunuşu nasıl olmalıdır?}

Eski Türkçe $\{$-mXş\} eki, BK yazıtında $¥$ ş harfi ile yazılırken, KT yazıtı ve diğer Runik harfli metinlerde I s ile yazılmıştır. TeKiN, ekin ünlüsünün /I/ olduğunu ve ünlü uyumu kurallarına aykırı olduğunu söyleyip eki \{-mIş\} olarak kabul etmiştir (2016: 36, 55-56). ŞÜKÜRLÜ, Köl Tigin, Ongin ve Tunukuk yazıtında ekin $120 \mathrm{kez}$ I s harfiyle, 13 kez de $¥$ Ş harfiyle yazıldığını belirtip ekin aslî şeklinin \{mIs\} olduğunu, \{-mIş\} varyantının ikincil olduğunu ifade etmiştir (2001: 350-351). ERDAL da ek hakkında TEKiN gibi düşünmüş ve Orhun yazıtlarında ekin sadece \{miş\} şeklinin olabileceğini söylemiş, ancak ekin ünsüzünün belirsizliğine işaret edip henüz bu sorunun çözülemediğini ifade etmiştir (2004: 55, 83). HOVDHAUGEN, bu konuda iki ihtimalin olabileceğini söylemektedir. İlki $¥$ Ş işaretinin Tunukuk yazıtında sadece iki kez kullanıldığını, ama KT ve BK yazıtlarında birçok yerde olduğunu belirterek $¥$ ş işaretinin yazıtların mevcut imlâ geleneklerinden birinde terk edildiğini ifade etmiştir. $O$ hâlde, damaksıl sürtünmeli /ş/ ünsüzünün 


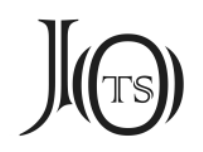

I s ile temsil edilmesinin yadırganmaması gerekmektedir. İkinci ihtimal olarak da ekin sonundaki tutarsızlığın nedeninin /s/ ve /ş/ ünsüzlerinin o dönemdeki telaffuz farklılıklarından kaynaklanabileceğini düşünmüştür (1974: 64-65). \{mXş\} ekinin sonundaki ünsüzün imlâ tutarsızlığının nedenini HovdHAUGEN'in iddia ettiği gibi epigrafik bir nedene bağlamak mümkündür. Dolayısıyla KT D23 = BK D19'daki ikilemeyi ermiş barmış olarak okumak yanlış olmayacaktır. Ayrıca, BK D19'da barmış tahrip olduğu için kelime tam olarak görünmez. Üstelik yazıtın kopyasını sunan çalışmalarda ermiş'in sonundaki ünsüz bazılarında /s/, bazılarında /ş/ ile gösterilmiştir. Bk. aşağıdaki tablo. Sonuç itibariyle, BK D19'daki yer için net bir şey söylemek şimdilik zordur.

\section{KT D23 = BK D19'daki ermiş barmışikilemesi kendisinden önceki keli- melerle ilişkili midir?}

KT ve BK yazıtlarında cümlenin öncesi aynı değildir. KT D23'te Igdms bIlgA QGNyN ig(i)dm(i)şbilge $k(a) g(a) n(l) \eta(l) n$ varken, BK D19'da Igdms QGNyA ig(i)dm(i)ş $k(a) g(a) n(1)$ ya bulunmaktadır. Buna göre, KT D23'teki $k(a) g(a) n(1) \eta(1) n$ ibaresine cümlede bir anlam vermek mümkün değildir. BK D19'daki $k(a) g(a) n(1) \eta a$ ibaresi muhtemelen daha doğrudur. Ancak BK D19'da KT D23'teki bilge mevcut değildir. Bu da yazıcının unuttuğu bir kelime olarak düşünülebilir. HovDHAUGEN'in belirttiği üzere iki yazıtın yazıcıları veya taşa kazıyanları aynı değildir. İki yazıt arasında ciddi farklar mevcuttur. KT yazıtı 732, BK yazıtı ise 735'te dikilmiştir. Yazıcı 3 senelik zaman zarfında imlâ bilgisini değiştiremeyeceğine göre iki yazıtın yazıcısının farklı olduğunu düşünmek daha mantıklıdır. Diğer taraftan BK yazıtının imlâsı KT yazıtına nazaran daha tutarlıdır (1974: 79).

Şimdi, ermiş barmış ikilemesinin öncesindeki kelime gurubunun iki yazıttaki durumuna bakalım:

\begin{tabular}{|c|c|}
\hline KT D23 & $\begin{array}{l}\text { kür(e)güy(i)n üçün ig(i)dm(i)ş bilge k(a)g(a)n(1)y(1)n (e)rm(i)ş b(a)rm(1)ş (e)dgü } \\
\text { (é)l(i)ye k(e)ntü y(a)y(1)lt(1)g y(a)bl(a)k kigürt(ü)g }\end{array}$ \\
\hline BK D19 & 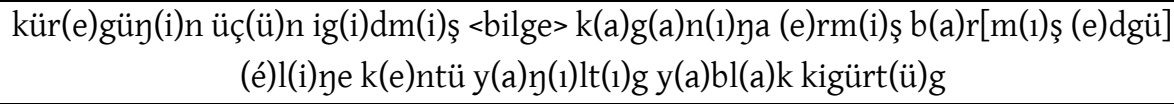 \\
\hline
\end{tabular}

İki yazıtı karşılaştırarak, THOMSEN'in daha önce düşündüğü üzere, Bilge Kagan'ın ağzından çıan cümlenin muhtemelen şöyle olabileceği tahmin edilebilir: 


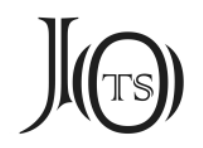

kür(e)gün(i)n üç(ü)n ig(i)dm(i)ş bilge k(a)g(a)n(1)ya (e)rm(i)ş b(a)rm(1)ş (e)dgü (é)l(i)ทe

$k(e) n t u ̈ y(a) \eta(1) \operatorname{lt}(1) g$.

Cümlenin yüklemi olan yayıltıg'ın kanaatimce iki tane tamlayıcısı bulun-

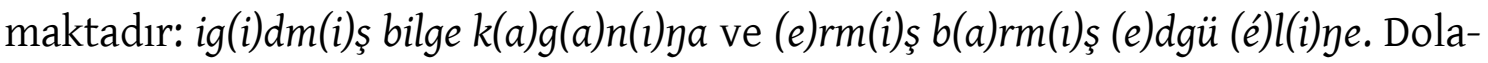
yısıyla, ermiş barmış'ın kendisinden öncesiyle bir ilişkisi bulunduğu söylenemez. Buna göre, ermiş barmış cümlede edgü él'i niteleyen bir sıfatfiildir.

\section{KT K1 ve BK D29'daki rklI şeklinde yazllan kelimenin okunuşu ve an- lamı konusunda ihtilaf var mıdır?}

KT K1 ve BK D29'da rkli şeklinde yazılan kelimenin bazı neşirlerde erikli veya erkeli olarak okunduğu görülmektedir. Mesela, ABDURAHMONOV-Rustamov, erkli'yi bazılarının sıfat, bazılarının sıfatfiil olarak kabul ettiğini belirtip kelimenin \{-gAlI\} ile teşkil edilen bir zarffiil olabileceğini düşünmüş ve kelimeyi neşirlerinde erkeli şeklinde okumuştur (1982: 119). TekiN, kelimeyi 'donmuş eylem s1fatı' olarak adlandırır ve kelimenin 'iken' anlamıla zarf işlevinde kullanıldığını belirtir (1968: 180, 186; 2016: 163). Aslında TeKiN'in tespiti doğrudan THOMSEN'in Turcica'daki erikli (sic!) hakkındaki notuna dayanmaktadır (2002 [1916]: 379-380). Kelimenin yapısı aslında oldukça açıktır. Eski Türkçe er- 'olmak' fiilinin üzerine \{-(X)glI\} zarffiil ekinin getirilmesiyle erkli meydana gelmiștir. ERDAL, kelimeyi 'sona gelen bağlaç' (pospositive conjunction) olarak adlandırmıştır. Ayrıca \{(X)glI\} ekindeki /g/'nin yazıtlarda / $\mathrm{k}$ / şeklinde olmasını 'heceleme' (syllabification) ile açılamıştır. ${ }^{2}$ Eski Türkçede / $\mathrm{rg} /$ şeklinde ünsüz çiftine rastlanmamaktadır. Ona göre, muhtemelen /r/, /l/ ve /n/'den sonra /k/ ünsüzü yazıtlarda /g/ olarak telaffuz ediliyordu (2004: 78, 121, 287). Netice olarak, yazıtlarda rkli şeklinde yazılan kelimenin erkli olarak okunup 'iken' ile anlamlandırılmasında bir şüphenin olmadığı söylenebilir.

ТЕKin, erkli'yi <*ergli < *erigli şeklinde açıklayıp /i/'nin düşmesi neticesinde /g/'nin ötümsüzleştiğini düşünmüştür (1988: 85). 


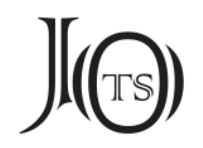

\section{BK D29'daki cümlede yer alan Bw̧Sz imlâlı kelimenin okunuşu buys (I)z mi yoksa buys( $u) z$ mu olmalıdır?}

ТЕкіN, yazıtlarda dudak uyumuna aykırı ekler arasında $\{+$ SXz $\}$ ekine de yer vermiş ve ekin yazıtlarda \{+sIz\} şeklinde olduğunu ifade etmiştir (2016: 58). ERDAL da ekin aslının \{+sIz\} şeklinde olabileceğini düşünmektedir (2004: 87, dip. 149). Ek, Eski Uygurcada $\{+$ sXz $\}$ şeklindedir. Orhun yazıtlarında $\{+$ sXz $\}$ ekinin $\{+$ sIz\} olduğu konusunda elimizde kesin deliller bulunmamaktadır, zira bu durum yazitların imlâ geleneğiyle de alakalı olabilir. Yazıtlarda ikinci ve müteakip hecelerde yuvarlak ünlülerin yazılmadığı durumlara rastlanıyor. Bu konuyu başka bir makalemde daha uzun ele alacağım için şimdilik daha fazla bir şey söylemek istemiyorum.

Yazıtların kopyasını sunan dört çalışmada er- bar-ikilemesini nasıl gösterildiğine bakalım:

\begin{tabular}{|c|c|c|c|c|}
\hline Kopya & KT D23 & BK D19 & KT K1 & BK D29 \\
\hline $\begin{array}{c}\text { Inscriptions } \\
\text { de l'Orkhon } \\
\text { 1892: } 3,15,10 \text {, } \\
14\end{array}$ & $\begin{array}{l}|\gg 4 \partial| \otimes \gamma \\
\text { rmsBRms }\end{array}$ & 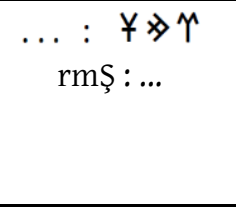 & $\begin{array}{c}4>4 J \uparrow N \uparrow \\
\text { rẅrBRwR }\end{array}$ & $\begin{array}{c}\text { 4> } 4 \mathrm{U}: \uparrow N \\
\ldots \ddot{\mathrm{w} r}: \text { BRwR }\end{array}$ \\
\hline $\begin{array}{c}\text { Radloff 1893: } \\
\text { XVIII, XXIII, } \\
\text { XX } \\
\end{array}$ & $\begin{array}{l}|\gg 4 J| \otimes \gamma \\
\text { rmsBRms }\end{array}$ & $\begin{array}{c}\ldots: \mid \otimes \uparrow \\
\text { rms }: \ldots\end{array}$ & $\begin{array}{l}4>4 J \uparrow H D \\
\text { YRrBRwR }\end{array}$ & $\begin{array}{c}4>40: \Upsilon N \ldots \\
\quad . . . \ddot{r} r: B R w R\end{array}$ \\
\hline $\begin{array}{c}\text { Radloff 1896: } \\
\text { XCVIII, C, } \\
\text { XCIX } \\
\end{array}$ & $\begin{array}{l}|\gg 4 J| \gg\rangle \\
\text { rmsBRms }\end{array}$ & $\begin{array}{c}\ldots: \mid \otimes \uparrow \\
\text { rms }: \ldots\end{array}$ & $\begin{array}{l}4>4 J \Upsilon N \uparrow \\
\text { rẅrBRwR }\end{array}$ & $\begin{array}{l}4>4 \Omega: \uparrow N \\
\quad . . . \ddot{W r} \text { : BRwR }\end{array}$ \\
\hline $\begin{array}{c}\text { Alyılmaz } \\
\text { 2005: 45-46, } \\
55,129-130\end{array}$ & $\begin{array}{l}|\gg 4 J| \otimes \gamma \\
\text { rmsBRms }\end{array}$ & $\begin{array}{c}\ldots 40: \quad ¥ \gg \uparrow \\
\text { rmŞ: BR... }\end{array}$ & $\begin{array}{c}4>4 J \uparrow N \uparrow \\
\text { rẅrBRwR }\end{array}$ & $\begin{array}{l}4>40: \Upsilon N \\
\quad . . . \ddot{W r}: \text { BRwR }\end{array}$ \\
\hline
\end{tabular}

İkilemedeki ilk unsurun ér- 'ulaşmak, varmak' olabileceği daha önce CLAUson ve TEKin tarafından ileri sürülmüştür. Ben fiilin ér- 'ulaşmak' olmayacağı kanaatindeyim. Bunun gerekçelerinden bir tanesi olarak fiilin imlâsı gösterilebilir. Yazıtlarda kelime başındaki /é/ ve /i/ ünlülerin çoğu zaman yazıldığı bilinmektedir. Şayet burada ér- olsaydı baştaki ünlü yazılacaktı. Zaten ér- fiili ve onun ettirgen gövdesi értür-'ün baştaki ünlüleri yazıtların başka yerinde yazılmıştır. Krş. 


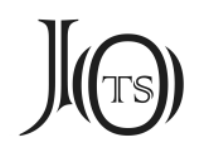

T 45 ve KT D40. Hâlbuki yazıtlarda kelime başında /a/ ve /e/ ünlülerinin genellikle yazılmadığı bilinmektedir. Yazıtların imlâ kaidelerine dayanarak ikilemenin ilk fiilinin ér- 'ulaşmak' ile ilişkilendirmeye gerek olmadığı söylenebilir.

Yazıtlardaki er- bar- ikilemesindeki iki fiil de kanaatimce geçtiği yerlerde gerçek anlamıyla kullanılmıştır. Eski Türkçede er- fiilinin yardımcı fiil olarak kullanılması dışında fiilin asıl anlamı 'mevcut olmak' olarak gösterilmiştir (Clauson 1972: 193b; Nadalyayev et al. 1969: 175b). Yazitlarda er-'in 'bir yerde mevcut olmak, bulunmak' anlamında kullanımı için bk. (é)ki sü (e)bde (e)rti (BK D32) “íki ordu karargâhta bulunmaktaydı/mevcut idi"; b(e)n(i)y bod(u)n(u)m (a)nta (e)rür (T 21) "Benim halkım orada bulunur/mevcuttur (mevcut olacaktır)". Diğer taraftan, er- fiilinin bu anlamına Eski Uygurca metinlerde de rastlanmaktadır. Krş. er'1. var olmak, bulunmak, mevcut olmak, meydana gelmek; 2. (bir şeye) sahip olmak, malik olmak' (Röhrborn 2010: 158-159). Ben er- bar-ikilemesinde de er-'in bu anlamlarda olduğu fikrindeyim.

İkilemedeki asıl sorun ikinci fiildir. Şimdiye kadar bar- fiilinin 'gitmek' anlamından hareketle fiilin dört yerde çeşitli anlamlarda olabileceği düşünülmüş ve ikilemenin geçtiği pasajlar farklı olarak yorumlanmıştır. Zaten CLAUSON ve TEKiN de bar- fiiline dayanarak ilk kelimenin onunla benzer anlama sahip olan érolabileceğini tahmin etmiştir. Ben Eski Türkçede bar- 'sahip olmak, mevcut olmak, bulunmak' gibi anlamlara gelen, ama bar- 'gitmek' ile eşsessli ve eşyazımlı olan başka bir fiilin daha mevcut olduğunu tahmin ediyorum. Daha önce er-barikilemesinin anlamını ERDAL doğru tahmin etmiş, ama bunun delillerini göstermemiştir. Aynı şekilde KARCAUBAY da KT D23'te bar- 'var olmak' fiilinin varlığından bahsetmiş, ama bunu filolojik delillerle açıklamamıştır. Şimdi iddiamın filolojik dayanaklarını ortaya koymaya çalışacağım.

Eski Türkçede 'mal, çiftlik hayvanı, servet' anlamına gelen barım sözcüğüne rastlanmaktadır. CLAUSON, sözcüğü bar 'var' ile ilişkilendirmiştir (1972: 366a). MoRi, barım sözcüğünün 'servet, mal, at' gibi anlamlarına dikkat çekmiş, ama kelimenin yapısı hakkında bir fikir beyan etmemiştir (1987: 350-351). ERDAL ise barım'ı fiilden isim yapan $\{-(\mathrm{X}) \mathrm{m}\}$ ekli gövdelerin içerisinde incelemiş ve kelimenin bar- 'gitmek' fiilinden türediğini iddia etmiştir (1991: 292-293). TEKiN, barım 'mal, 


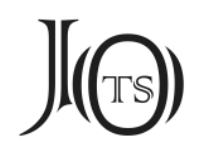

mülk, servet' kelimesinin tanıklanmamış *barı- 'tutmak, elde etmek' (krş. Moğolca bari- 'elde etmek, tutmak, yakalamak, gasp etmek') fiiline dayandığını düşünmektedir (2016: 89).

Clauson'un görüşü kabul edilemez, zira Eski Türkçede isimden isim yapan \{+(X)m\} eki yoktur. ERDAL'1n görüşüne gelince, bar- 'gitmek' kökünden 'mal, çiftlik hayvanı, servet' anlamında bir sözcüğün ortaya çıkması zor gibidir. Muhtemelen Türklerin göçebe hayat tarzı düşünülerek böyle bir köken önerisi teklif edilmiştir. Bence yazıtlarda görülen barım sözcügünün kökü Eski Türkçede var olduğunu düşündüğüm bar- 'mevcut olmak, bulunmak, sahip olmak' fiiline dayanmaktadır. Bu köken teklifinde, barım'ın anlamı ile ait olduğu bar- 'mevcut olmak, bulunmak' kökü arasındaki anlamsal ilişki oldukça açık görülebilmektedir. Ayrıca bozkır hayatında Eski Türklerin 'sahip olduğu' en değerli servetin 'mal, çiftlik hayvanı, at' olduğunu da düşünürsek önerdiğim köken teklifinin oldukça mantıklı olduğu anlaşılacaktır. Yazıtlarda barım'ın geçtiği yerler için krş. KT K1, BK D39, vs.

Eski Türkçe barım kelimesinin dolaylı da olsa 'mevcut olmak, bulunmak' anlamındaki bar-fiiline dayandığı daha önce RóNA-TAS ve ÁRPÁD tarafından tahmin edilmiştir (2011: 99-103). RóNA-TAS ve ÁRPÁD, Macarcadaki barom'un 'büyük baş hayvanı, çiftlik hayvanı' Eski Batı Türkçesinden alıntı olduğunu ve Macarca kelimenin Türkçedeki bar- 'var olmak, mevcut olmak' anlamındaki fiilden kaynaklandığını düşünmüştür. Onlar, Eski Doğu Türkçesinde barım'ın bar ile ilişkisine ihtimal vermiş, ama Macarca barom için kelimenin 'gitmek' anlamına gelen barile ilgisini zayıf görüp Macarcadaki barom'u Eski Batı Türkçesindeki *bar- 'var olmak' fiilinden kaynaklandığını düşünmüştür.

Yazıtlarda görülen bark da muhtemelen bar- 'var olmak' fiili kaynaklıdır. Fiilin 'var olmak, sahip olmak' gibi anlamından ‘mülk' anlamındaki bir ismin ortaya çıkması oldukça muhtemel gözükmektedir. Ancak yazıtlarda bark, eb sözcü̆̆ü ile beraber kullanıldığı yerlerde 'mülk, yaşam yeri' anlamındayken (BK D32, 34, 37), eb olmadan kullanıldığ yerlerde de 'anıt mezar külliyesi' anlamında (KT G12 = BK K15, KT K13, vs.) olmalıdır. ${ }^{3}$ Eski Türkçede /r/ ile biten tek heceli fiil köklerinin

ABDURAHMONOV-RUSTAMOV, diğer filologların bark'ı 'bina' anlamında düşündüğünü ifade edip bu görüşten farklı olarak kelimenin barak şeklinde okunması gerektiğini ve kökünün bar- 'gitmek' fiiline 


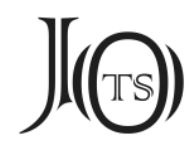

üzerine fiilden isim yapan $\{-(\mathrm{X}) \mathrm{k}\}$ eki geldiğinde ekin yardımcı ünlüsünün düştüğü görülüyor. Mesela, körk (< ör-ük), örk (< ör-ük), turk (< tur-uk), vs. (Erdal 1991: 224-225). Dolayısıyla bark'ın *barık şeklinde görülmeyişi Eski Türkçenin seslik özellikleri bakımından olağan bir durumdur. CLAuson, bark'ın kökünün bar 'var' ismine dayandığını tahmin etmiştir (1972: 359b). TIETZE ise bark'ın kökeni hakkında bir şey söylememiş, ama barın- 'bir şeye karşı korunmak için bir yere sığınmak' fiilinin Eski Türkçe bar- 'gitmek' ile ilgili olabileceğini ifade etmiştir (2002: 281b, 282b). Şinasi TeKiN, bark kelimesi hakkında mükemmel bir köken araştırması neşretmiştir (1991: 10-13). TEKiN'in makalesinde Türk dili tarihindeki bark ile ilgili tanıklar listelendiği için burada onları tekrar zikretmeyeceğim. Sadece TeKiN'in tespitlerine ufak bir katkı sunacağım. Tekin, çalışmasında ‘*bir kimseyi, bir şeyi bir yere bağlamak, yerleștirmek' şeklinde kök anlama sahip tanıklanmamış bir *bar- kökünden $\{-(\mathrm{X}) \mathrm{k}\}$ ekiyle bark'ın türetildiğini düşünmüştür. Ona göre, bar-fiili ba- 'bağlamak' köküne dayanmaktadır. Eski Türkçe bar- fiilinin Türkçenin sonraki dönemlerinde 'muhafaza etmek, emin bir yere sokmak' anlamını kazandığını söylemiştir. Eski Türkçede bar- kelimesinin asıl anlamları arasında TekiN'in önerdiği anlamlara ilave olarak 'sahip olmak, bulunmak' anlamının da olduğunu düşünüyorum. TeKiN'in sözlüklerden topladığı bar- için verilen 'korumak, siper altına girmek, gemileri limana sokmak, bakmak, kendine gelmek, kökleşmek, tutmak' gibi anlamların belki de Moğolcada olduğu gibi“ 'mevcut olmak, bulunmak' kök anlamından çıkmasının daha muhtemel olabileceğini tahmin ediyorum. $\mathrm{Bu}$ anlamda İngilizcedeki to hold kelimesi de Eski Türkçe bar- ile benzer anlam genişlemelerini yaşamıştır. İngilizcede to hold 'tutmak, sığınmak,

dayandığını, böylece barak’ın 'ziyaretgâh' anlamının açıklanabilir olabileceğini düşünmektedir (1982: 93).

4 Eski Türkçe 'mevcut olmak, bulunmak' anlamındaki bar- belki de Moğolca bari- ile denktir. Altay dillerinin köken sözlüğünde Moğolca bari- 'inşa etmek' ile Türkçe bark (<b(i)ar-k) denkliği tasarlanmıştır (Starostin et al. 2003: 346). Eski Türkçe bar- 'var olmak' fiilinin mevcudiyeti bilinmediği için bu denklikle yetinilmiştir. Türkçede, uzun asırlar içerisinde birçok sözlerin heceleri düşüp sözler kısaldığ1 hâlde, Moğolcada bazı sözlerdeki açık hecelerin son vokalleri varlığını muhafaza etmiştir. Mesela, Türkçe kök 'mavi' = Moğolca köke, Türkçe tün 'gece' \# Moğolca tüne, vs. (Temir 1955: 10). Buna göre, Türkçe bar- ile Moğolca bari- denkliği seslik bakımdan mümkün gözükmektedir. Ancak Moğolcada fiilin oldukça çeşitli anlamlarının olduğu görülüyor: '1. tutmak, muhafaza etmek; 2. bina etmek, yerleştirmek; 3. idare etmek, kontrol etmek; 4. sunmak, arz etmek; 5. şekil vermek' (Lessing 1960: 85b86a). Tabii bu anlamlar fiilin asıl anlamları arasında 'var olmak' olabileceğini de akla getirmektedir. 


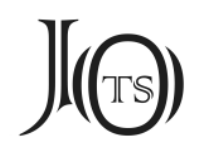

korumak, sahip olmak' gibi çeşitli anlamlara sahiptir. Diğer taraftan, Eski Türkçede bark'ın 'menkul, mülk, mesken, ev eşyası' gibi anlamlarına bakınca gövdenin 'mevcut olmak, bulunmak' anlamındaki bir bar- fiilinden türediğini düşünmenin yanlış olamayacağı söylenebilir.

Orhun yazıtlarında 'var olmak, bulunmak, mevcut olmak, meydana gelmek' anlamındaki bar-fiili yazıtlarda başka yerde geçmekte midir? Çöyr yazıtındaki şu cümle dikkat çekicidir: ög(ü)ni s(e)b(i)ni b(a)r(i)y. ÖzÖNDER, cümleyi “Öğünerek-sevinerek ${ }_{2}$ hayat sürün" (2006: 113) şeklinde anlamlandırmıştır. Buradaki bar-fiili 'yaşamak' anlamındadır ve er- bar-ikilemesindeki bar-ile muhtemelen aynı anlamda kullanılmıştır.

Kutadgu Bilig'te 'hepsi, tamamı, tamamen, bütün' gibi anlamlara gelen baru kelimesi bulunmaktadır. Bu kelimeyi Eski Türkçe barı 'hepsi' ile karıştırmamak gerekiyor, zira barl $(<$ bar +1$)$ muhtemelen bar isminin üzerine gelen iyelik ekinin kalıplaşmasıyla meydana gelmiştir. Kutadgu Bilig dizinine göre baru 'bütünü, tamamı, hepsi' sadece B/59'da geçmektedir (1979: 60). Aslında eserde baru B/59, 736, 4161, 4708, 5757, 6486 ve 6490 . beyitlerde toplam yedi yerde geçiyor (Arat 1947: 9, 90, 419, 472, 571, 640). TEZCAN, 736, 4708, 6486 ve 6490. beyitlerdeki baru'nun art- 'çoğalmak' ile beraber kullanımında 'gittikçe' anlamında olduğunu düşünmüştür (1981: 33) $)^{5}$. TEZCAN'ın baru için önerdiği 'gittikçe' anlamı baru'nun geçtiği bütün yerler için kabul edilemez, zira baru sadece 4161. (baru turg̉u), 6486. (baru arttl) ve 6490. (baru artadl) beyitlerde bir fiili nitelemektedir, ama diğer 3 yerde bir ismi nitelemiștir: baru körki (736), baru edgü (4708) ve baru kılḳl (5757). Sadece bir yerde de isim olarak kullanılmıştır: barusın (B/59). TEZCAN'ın önerisi belki 4161, 6486 ve 6490. beyitler için kabul edilebilir. Kanaatimce baru, bar- 'var olmak' fiilinin üzerine getirilen \{-U\} zarffiil ekinin kalıplaşmasıyla teşekkül etmiş olmalıdır. Buna göre, baru ismi niteleyip sıfat olarak kullanıldığı yerlerde 'bütün' (736, 4708 ve 5757. beyitler), fiili niteleyip zarf olarak kullanıldığı yerlerde 'tamamen' (4161, 6486 ve 6490. beyitler) ve isim olarak kullanıldığı yerde de 'hepsi,

5 Eğer Eski Türkçede bar- 'gitmek' fiilinden 'gittikçe' anlamında bir zarf yapılmak istenseydi, bunu ünlü zarffiil eki $\{-U\}$ ile değil, \{-gInçA\} ekiyle yapılması gerekirdi. Krş. Yeni Uygurca bargançe 'gittikçe’ (Schwarz 1992: 60a). 


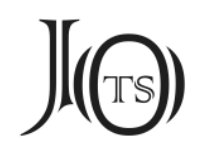

tamamı' (B/59. beyit) anlaminda olmalıdır. Netice olarak, Kutadgu Bilig'te 'var olmak' anlamında bir bar- fiilinin mevcut olduğu söylenebilir. Bu arada, Eski Türkçenin sözlüklerinde sadece Drevnetyurkskiy Slovar'da baru'nun olduğu görülüyor, orada da sadece Kutadgu Bilig'in B/59. beytindeki tanık zikredilmiştir (Nadelyayev et al. 1969: 85a). Son tahlilde, Eski Türkçe bar- 'mevcut olmak' fiiline dayanan baru şeklinde kalıplaşmış bir zarffiilin olduğu söylenebilir.

Eski Türkçede görülen barın- ile bugün Türkiye Türkçesindeki barın-'1 anlamsal bakımından birbiriyle ilişkilendirmek mümkün değildir. Divanü Lugati'tTürk'te Kaşgarî iki yerde barın- fiiline yer vermiştir, ancak muhtemelen ikisi de bar- 'gitmek' ile ilgilidir: uraguttın ḳan barındı (Dankoff-Kelly 1984: 338 [s. 34]) "Kadından kan fışkırdı"; ol ewke barındı (Dankoff-Kelly 1984: 346 [s. 42]) "O, eve gider gibi yaptı, ama aslında gitmedi”. Görüldüğü üzere, barın- ilk cümlede 'fışkırmak', ikinci cümlede 'gider gibi yapmak' anlamındadır. CLAUson, Osmanlıcadaki (ve Türkiye Türkçesindeki) 'barınmak' anlamındaki barın-'a rağmen fiilin kökünü bar- 'gitmek' olarak düşünmüş ve kelimenin sadece Osmanlı sahasında ‘yaşamını sürdürmek' olarak yaşadığını ileri sürmüştür (1972: 367b). Eski Türkçe barın- 'fışkırmak' için ayrıca bk. Erdal 1991: 592. Hâlbuki Eski Türkiye Türkçesindeki barın- tanıklarının Divanü Lugati't-Türk'teki tanıklarla anlamsal bir bağı sözkonusu değildir. Eski Türkiye Türkçesi döneminden kalan iki eserde barın- mevcuttur. Biri XV. yüzyıldan kalan mensur eser Ferec ba'd eş-şidde' de geçer: baya don bagışladı altun bagışladı bu vakta dek anuyıla barınurdum (Hazai-Tietze 2006: 92b/1 [s. 291]). Diğeri de XIV. yüzylldan kalan Süheyl ü Nev-bahâr mesnevisindedir: yémiş miş̧ede bulunur idi bol // anı yéyüben barınur idi ol. Tarama Sözlüğü’nde barın-'a 'geçinmek, kendini yaşatmak' anlamı verilmiştir (TS: 401). Bugün Türkiye Türkçesinde barın'’n anlamı sözlükte şöyle kaydedilmiştir: “1. Doğa etkilerinden korunmak için kapalı bir yere sığınmak; 2. Yerleşmek, yaşamak için uygun şartlar bularak oturmak; 3. Bir yerde yatarak geceyi geçirmek; 4. mec. Çevresiyle uyumlu, dirlik içinde yaşamak. 5. mec. Bir yerde etkili olmak, gelişecek ortamı bulmak" (Parlatır et al. 1998: 219b-220a). Anadolu Ağızlarında da fiil büyük ölçüde aynı anlamdadır: barın- '1. Bulunduğu durumu uzun süre muhafaza etmek; 2. Bir yerde çalışmak; 3. Geçinmek; 4. Az çok geçim temin etmek; 5. Kuvvetlenmek, kendine gelmek; 6 . Tatmin etmek' ve barınmah ‘sığınmak, korunmak, 


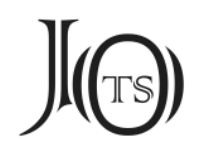

ihtiyacını sağlamak' (DS: 532b). Görüldüğü üzere, bugün Türkiye Türkçesindeki anlamlar fiilin 'bulunmak, mevcut olmak' anlamından ortaya çıtı̆̆̆na işaret etmektedir.

TRYJARSKI'nin neşrettiği Ermeni Kipçakçası sözlüğünde barıgsız 'malsız, fakir' (1968: 113) tanığı da Eski Türkçe bar- ile ilgili olmalıdır. Sözlükteki barıgsız, bar-ıg+sız şeklinde tahlil edilebileceğine göre bar-fiilinin Ermeni Kıpçakçasında mevcudiyeti ispatlanmış olmaktadır. RADLOFF, Türk diyalektleri sözlüğünde Çağatayca olarak baruk 'mal, mülk' kelimesini kaydetmiştir (1911: 1482). Bu kelimeyi (< bar-uk) Çağatayca metinlerde tanıklayamadım.

Eski Uygurcada bazı metinlerde erig barıg ikilemesine rastlanmaktadır. İkileme 'davranış2, tutum,' anlamındadır. CLAUSON, erig barıg için şüpheyle de olsa 'hareket ${ }_{2}$ ' anlamını vermiştir (221b). ${ }^{6}$ ERDAL, erig' in farklı anlamlarındaki kullanışına bakılarak tek bir leksem olarak değerlendirilmesinin zorluğuna işaret etmiş ve 'bir şeyin olma tarzı' anlamından 'davranış2, tutum, anlamını kazandığını ifade etmiştir (1991: 186-187). RöHRBORN, erig'in er- fiilinin 'bulunmak, (bir yerde) kalmak, oturmak, ikamet etmek' anlamından türemiş olabileceğini belirtmiş ve erig' in '1. oturulan yer, asıl kalınan yer, ikametgâh; 2. davranış, tutum, yaşam biçimi' anlamlarını kaydetmiştir (2017: 251-253). ERDAL'ın da belirttiği üzere Eski Uygurcada erig'in çeşitli anlamları bulunmaktadır ve bunlar er- fiilinin zengin anlamları arasından ortaya çıkmıştır. Eski Uygurcada 'davranış2, tutum, anlamindaki erig'in er- fiilinin 'var olmak, bulunmak, mevcut olmak, meydana gelmek' anlamindan türemiş olabileceği kanaatindeyim.

Eski Uygurcadaki ikilemelere genel olarak bakıldığında, ikilemelerin (üçlemelerin veya dörtlemelerin) çoğunlukla yakın veya eş anlamlı kelime birliklerin$\operatorname{den}^{7}$ meydana geldiği görülmektedir. Mesela aç- belgürt- 'izah etmek ${ }_{2}$, ada tuda

6 CLAuson'un erig barıg için teklif ettiği 'hareket' anlamı oldukça isabetlidir. Bu anlamı esas alarak Eski Uygurcada ikilemenin geçtiği bazı yerleri doğru anlamlandırmak mümkündür. Mesela, Daśakarmapathāvadānamālā'da geçen şu cümleye bakalım: élgin adakın arçuné tonag ölürgülük erig barıg kılıp. Bu cümledeki éligin adakın erig barıg kıl- ibaresi 'elini ayağını hareket ettirmek, oynatmak', yani 'jest yapmak' anlamındadır. İbare için bk. Röhrborn 2017: 253.

7 BROCKELMANN, muhtemelen ikilemeleri oluşturan unsurların benzer veya yakın anlamlı olmasına bakarak onları Synonymkomposita (eşçift) diye adlandırmıştır (1954: 144-147). RöHRBORN ise, Worthäufung (kelime yığını) terimini tercih etmiştir (2010: XVII). 


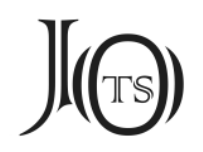

'tehlike ${ }_{2}$, vs. Daha az olsa da tünle küntüz 'gece gündüz' ( $\rightarrow$ 'devaml ${ }_{2}$ ') gibi zit anlamlı unsurlardan oluşan ikilemeler de görülmektedir. Şimdiye değin, Eski Uygurcada erig barıg ibaresi ikileme olarak kabul edilmiştir. O hâlde, iki unsur ne tür bir anlam ilişkisiyle birliktelik meydana getirmiştir? Acaba erig ve barıg yakın, eş ya da zıt anlamlı kelimeler midir? Eğer barıg'ın kaynağı olarak bar- 'gitmek' fiili düşünülecekse, 'gitmek' anlamına gelen bar- fiili, 'var olmak, bulunmak, mevcut olmak, meydana gelmek' anlamındaki er- fiili ile ikileme birlikteliğinde anlam bakımından nasıl bir ilişki içinde olmuştur? Buna göre, 'gitmek' anlamındaki barfiilinin bu anlamda er- fiili ile eş, yakın ya da zıt anlam bakımından bir ilişki içinde olması sözkonusu değildir. Belki de barıg 'var olmak, bulunmak, mevcut olmak, meydana gelmek' anlamındaki bar- fiiline dayanmaktadır. Yukarıda da belirtildiği üzere, erig barıg ikilemesi 'davranış2' anlamındadır. Bugün İngilizcede kullanılan to behave 'davranmak' ile behavior behaviour 'davranış' kelimelerinin to have 'sahip olmak, bulunmak' fiiline dayanması (Skeat 1888: 58a) oldukça enteresandır. Eğer Eski Türkçede 'var olmak, bulunmak, mevcut olmak, meydana gelmek' anlamındaki bar- fiilinin varlığını kabul edecek olursak erig barıg ikilemesinde de bu fiilin bulunduğunu söylemek mümkün olabilir.

\section{Bugünkü Türk dillerinde Eski Türkçe bar- 'var olmak' fiili veya bakiye- leri yaşamakta mıdır?}

Yakutçadaki barīnın 'kâr, kazanç' (Pekarskim' 1909: 381a) belki de Eski Türkçe bar- 'var olmak' fiilinden türetilen *barı ile ilişkili olabileceğini tahmin ediyorum. Tabii bu barıg yukarıda zikrettiğim Eski Uygurca erig barıg ikilemesindeki barı'tan farklı anlamda olmalıdır. Yakutçadaki barìnın anlamına bakıldığında bunun Eski Türkçe bar- 'gitmek' ile ilişkilendirilmesi pek mümkün gözükmemektedir. Belki de fiilden isim yapan $\{-(\mathrm{X})$ ş\} ekiyle aynı anlama gelen sözcük Hakasçada da meydana getirilmiştir. Krş. parıs 'kâr, kazanç' (Subrakova 2006: 348a).

Kırgızcadaki bark (I) ve müştakları da Eski Türkçe bar- 'var olmak' ile ilişkili olmalıdır. Krş. bark barık '1. fark, vasıf, hususiyet; 2. kıymet, değer' (Yudahin 1985: 110b-111a, 113a); barkta- barıkta- 'hürmet etmek, sayg1 göstermek' (Yudahin 1985: 111b, 113a); barktan- barkktan- 'kibirlenmek' (Yudahin 1985: 111b, 113a); barktū barıktū 'kıymetli' (Yudahin 1985: 111b, 113a); barktūluk 'kıymetli olma, 
otorite sahibi olma durumu' (Yudahin 1985:111b). Kirgizca bark ve bark'ın fiilden isim yapan \{-(X)k\} ekiyle bar- fiil kökünden türediği açıktır. Muhtemelen Kırgızcada bark 'varlık, var olma' $\rightarrow$ 'otorite' $\rightarrow$ 'sayg, itibar' gibi anlam evrelerinden geçerek bu anlamı kazanmıştır.

Bugün Çuvaşçada purăn- '1. yaşamak, oturmak; 2. var olmak, mevcut olmak, bulunmak' (Aşmarin 1999: 301-302) anlamina gelen bir fiil mevcuttur. Eski Batı Türkçesi/Ugrik dilindeki *barın- ile Çuvaşça purăn- denkliği daha önce gösterilmiştir (Agyagási 2019: 190). Çuvaşça purăn- fiili şüphesiz Eski Türkçe barın- ile ilişkilidir. Çuvaşça tanık aslında Eski Türkçede 'mevcut olmak, bulunmak' anlamına gelen bar- fiilinin mevcudiyetini göstermesi bakımından oldukça dikkate değerdir.

Eski Türkçedeki bar- 'mevcut olmak' fiili neden o dönemde yaygınlaşmadı veya bugünkü Türk dillerinde yaygın olarak varlığını sürdüremedi şeklindeki bir soruya kesin bir cevap vermek oldukça zordur. Belki de bunun nedeni bar-fiilinin isim şekli olan bar 'var' sözcüğünün varlığıdır. ${ }^{8}$ Türkçede bar sözcüğünün yaygınlaşması ve bar'ın yardımcı fiillerle birlikte kullanımı (mesela bar bolmak 'var olmak', vs.) bar- fiilinin kullanımdan düşmesine sebep olmuş olabilir.

Yukarıdaki etimolojik izahların ardından yazıtlardaki er-bar- ikilemesine dönebiliriz. Yazıtlardaki dört yerde ikilemelerin yer aldığı cümlelere bakalım:

\begin{tabular}{||c||c||}
\hline KT D23 = BK D19 & $\begin{array}{c}\text { kür(e)gün(i)n üç(ü)n ig(i)dm(i)ş bilge k(a)g(a)n(1)ya (e)rm(i)ş b(a)rm(1)ş } \\
\text { (e)dgü (é)l(i)ye k(e)ntü y(a)y(1)lt(1)g y(a)bl(a)k kigürt(ü)g }\end{array}$ \\
\hline \hline KT K1 & $\begin{array}{c}\text { köl tig(i)n : yiti ot(u)z : y(a)ş(1)ya : k(a)rluk : bod(u)n : (e)rür b(a)rur : (e)rkli } \\
\text { :y(a)gı boltı }\end{array}$ \\
\hline \hline BK D28-29 & ot(u)z (a)rtukı : bir : y(a)ş(1)ma : k(a)rluk : bod(u)n : buys(u)z (e)rür : \\
& b(a)rur : (e)rkli : y(a)gı boltı \\
\hline \hline
\end{tabular}

ERCiLASUN'un ifade ettiği üzere (2016: 637) ikileme dört yerde de birlikte değerlendirilmelidir. Bu nedenle, yazıtın birinde verilen anlam ile diğer yerlerde

\footnotetext{
8 Türkçede benzer anlama gelen, eşsesli ve eşyazımlı olan isim ve fiil kökleri mevcuttur. Mesela, aç 'aç' ve aç- 'aç olmak', kéç 'geç' ve kéç- 'geç olmak', tuş 'karşı' ve tuş- 'karşılaşmak', vs. Bu kelime çiftlerini listeleyen DOERFER, şimdiye kadar Türkçede böyle kelime çiftlerinin nadiren bulunduğu görüşünü çürüterek toplam 60 adet örnek tespit etmeyi başarmıştır (1982: 101-114). DOERFER'in listesinde bar 'var' ve bar- 'var olmak' bulunmaz. Listeye bunların da eklenebileceğini düşünüyorum.
} 


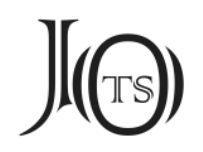

verilen anlam aynı olmalıdır, zira ikilemenin dört yerde farklı anlamda kullanıldığını düşünmemiz için herhangi bir sebep bulunmamaktadır.

KT D22-24. = BK D18-20. satırlar arasında Türklere, bilhassa Oğuzlara karş1 bir hitap ve azarlama vardır. Çin kaynakları, 716'da Kapgan Kagan'ın vefatıyla neticelenecek Türklerdeki büyük çözülmeden ve bazı Türk guruplarının Çin'e s1ğınıp Kapgan Kagan'a karşı Çin ile işbirliği yapmasından bahsetmektedir. Bu dönemde Türklerden bir gurup 10.000 çadırı dolduracak sayıda göçebe kitle Çin imparatoruna sığınıp Kapgan Kagan'a ihanet etmiştir (Thomsen 2002 [1896]: 96, 221-222). Bilge Kagan, bu kitleyi küreg olmakla ${ }^{9}$ yani 'isyankârlık' ile suçlayıp azarlamaktadır. İsyankârlık yapan bir kısım Türkler edgü ülkelerine ihanet edip ülkeye nifak sokmuştur. ${ }^{10} \mathrm{Bu}$ cümlede er-bar-ikilemesi $\{$-mXş\} ekli geçmiş zaman sıfatfiil ekiyle éline 'ülkene' sözünü nitelemektedir. Cümlede él 'devlet, ülke' unsurunun iki tane niteleyicisi vardır: ermiş barmış ve edgü. Cümledeki ermiş barmış'ın 'var olan, mevcut olan, yaşayan' anlamında olabileceğini tahmin ediyorum. Yazıtlarda bir bod'un veya bodun'un mevcudiyeti oldukça önemli olduğu bunun mevcut olmayışı dile getirilerek vurgulanmıştır. Krş. él yme bod(u)n yme yok (e)rt(e)çi (e)rti (T 55) “Ülke de halk da yok olacaktı”; türk sir bod(u)n y(é)rinte bod yme bod(u)n yme kişi yme idi yok (e)rt(e)çi (e)rti (T 59) "Türk Sir halkının ülkesinde kabile de boy da insan da hiç olmayacaktı"; türk bod(u)n (...) yok(a)du b(a)rır (e)rm(i)ş (KT D10) "Türk halkı yok olup gidecekmiş"; türk bod(u)n yok bolm(a)zun téy(i)n (KT D11) "Türk halkı yok olmasın diye"; (a)z bod(u)n (a)nta yok boltı (KT K3) "Az halkı orada yok oldu”. Görüldüğü üzere bir boyun var olup mevcudiyetini sürdürmesi oldukça önemli ve değerlidir. Dolayısıyla, Bilge Kagan'ın (e)rm(i)ş

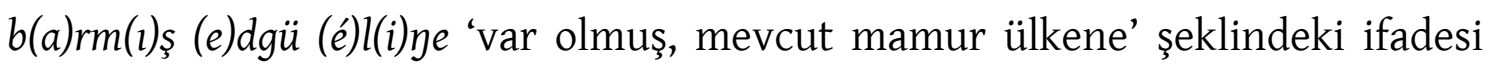
metnin bağlamı açısından oldukça uygundur. Böylelikle Kapgan Kagan'a ihanet

9 küregünin (< küre-gü+y+in) 'kaçak, isyankâr, itaatsiz, inatçı' için bk. Tekin 1988: 77 ve Erdal 2004: 303, dip. 492. Yazıtlardaki küregü'yü başka bir makalemde ayrıntılı olarak değerlendirmeyi planlıyorum.

10 TekiN’in yablak kigür- için düşündüğ̈̈ 'nifak sokmak' (1988: 15) anlamı bağlam açısından uygundur, ancak yazıtlarda yablak'ın 'nifak' anlamına başka bir yerde rastlanmaması düşündürücüdür. Bu cümledeki yablak belki de KT D26'daki yabız yablak bodun ibaresindeki yablak ile aynıdır. O hâlde, yablak kigür- 'sefalet getirmek' anlamında düşünülebilir. Türk toplulukları kagana ihanet edip ülkeyi terk edince ülkede birliğin bozulduğu düşünülebileceği gibi, bu ayrıllğın ülkeyi ekonomik olarak zayıflatıp ülkenin sefalete düşmesine neden olması da tahmin edilebilir. 


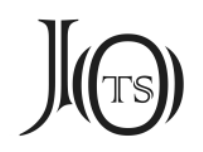

edip Çin'e sığınan bir kısım Türk kitlesi varlığını sürdüren mamur bir devlete ihanet etmiş olmaktadır.

KT K1 ve BK D29'da er- bar- ise \{-Ur\} geniş zaman çekiminde erkli 'iken' ile beraber bir zarffiil gurubu oluşturmuştur. Yukarıda erkli üzerinde durduğum için burada onları tekrar etmeyeceğim. Cümledeki er-bar-iki yazıtta da Karluklar ile yapılan mücadelenin anlatıldığı bağlamda geçmektedir. Karlukların düşman olmaya başlamasının tarihi konusunda yazıtlarda ihtilaf var gibi gözükmektedir. ${ }^{11}$ Bilge Kagan, Köl Tigin'in 27. yaşında Karlukların düşman olmasından bahsetmektedir (KT K1-2). Köl Tigin 684'te doğduğuna göre Karluklar 711'de düşman olmuştur. Benzer cümle BK D28-29'da mevcuttur. Orada Bilge Kagan, kendisi 31 yaşındayken Karlukların düşman olduğunu söylüyor. Bilge Kagan 683'te doğduğuna göre Karlukların düşmanlığının 714'te gerçekleştiğini söylemek mümkündür. Şimdi, Karluklar II. Türk Kağanlığına 711'de mi yoksa 714'te mi düşman olmuştur? İki yazıt Karluklarla olan savaşın tarihi konusunda ittifak etmektedir. Bilge Kagan, Köl Tigin 30 yaşındayken, yani 714'te Tamag Idok Baş'ta onlarla savaştığını söylemektedir (KT K1-2). Bilge Kagan, kendi yazıtında ise, 31 yaşındayken, yani 714'te Karluklar düşman olup onlarla Tamag Idok Baş'ta savaştığını söylemiştir (D28-29). Aslında Bilge Kagan KT yazıtında Köl Tigin'in yaşını kıstas alarak doğru tarihi zaten vermiştir, kendi yazıtında Karluklarla mücadelesini daha muhtasar vermek istediği için muhtemelen Karlukların düşman olduğu tarih ile onlarla savaşın tarihini aynı olarak göstermiştir. Fark edileceği üzere, Bilge Kagan, kendi yazıtında Karluklar hakkındaki savaşa doğrudan değinip neticeyi söylemiştir: $t(a) m(a) g l d(u) k b(a)$ şda süy(ü)şd(ü)m k(a)rluk bod(u)n(u)g öl(ü)rt(ü)m (a)nta (a)lt(i)m.

$\mathrm{Bu}$ arada Karluklar hakkında kısaca bilgi vermek faydalı olacaktır. Karluklar, Türk Kağanlığına akraba olan bir boydur. Karlukların I. ve II. Türk Kağanlığı

${ }_{11}$ Lí, iki yazıt arasında tarihlendirme konusunda yanlışlık olduğunu söylemiş ve KT K1'de Köl Tigin'in yaşının 27 değil, 30 olması gerektiğini iddia etmiştir (2008: 212-213). Eski Türk yazıtlarındaki kronoloji ile ilgili en son çalışmalardan birini neşreden HAO (2019: 320), daha önce MARQUART'ın ortaya koyduğu gibi (1898: 53), ilk Karluk isyanının 24 Ocak 711 ile 11 Şubat 712 arasında çıktığını, bu isyan esnasında Bilge Kagan'ın 28, Köl Tigin'in de 27 yaşında olduğunu ifade etmiştir. 


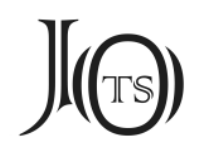

döneminde devlete karşı yaptığı isyanlarla meşhur olduğu anlaşıllyor. İlk isyanları 627'de Batı Türk Kağanı T’ung Yabgu'ya karşı olmuştur. Çin kaynakları Tang hanedanlığı döneminde Karlukların Çin'e tâbi olduğundan bahsetmektedir, ancak VII. yüzyılın ikinci yarısı ile VIII. yüzyılın başına kadar Çin kaynakları Karluklar hakkında bilgi vermez. Kapgan Kagan'ın baskıcı idaresi ve Çin'in tahrikiyle birçok boy isyan hareketini başlatmıştı. 711'deki isyan hareketi de bunlardan biridir. Karluklar da isyan eden boyların arasında bulunmaktaydı. Köl Tigin komutasındaki ordu 714 715'te Karlukları bozguna uğrattı. Daha sonra 716'da ve 720'de (?) de Karluklar üzerine çeşitli seferler düzenlenmiştir. (Ecsedy 1980: 2337; Taşağıl 2013: 62-72) Buna göre, 711'deki isyan ile Karluklar, II. Türk Kağanlığına düşmanlık yapmaya başlamış ve 714 715, 716 ve 720'deki mücadelelerin ardından Karluklar mağlup edilmiştir.

Çince kaynaklarda Karlukların çok önemli olduğuna dair bir bilgi bulunmaz. Çince kaynaklarda 葛邏祿 veya 歌邏祿 Geluolu olarak adlandırılan Karlukların bahsi geçen kaynaklarda bazı dönemlerde hiçbir bilginin ve kaydın olmadığı da görülmektedir (Ecsedy 1980: 23-37). Bu nedenle, Bilge Kagan'ın Karlukların 'müreffeh olduğunu' veya onların 'bağımsızlı̆̆ını' dile getirdiğini düşünmek için herhangi bir sebep yoktur. Bilge Kagan, yagı boltı demekle muhtemelen Karlukların isyan hareketine katıldığını ima etmiştir. Üstelik Karlukların 711'de isyan hareketine katıldıktan sonra Çin ile işbirliği yaptığı da bilinmektedir (MauTsai 2006: 307-308). Sonuç olarak, Bilge Kagan'ın Karluklar için erür barur erkli şeklinde söylediği ibareden Karlukların ‘müreffeh olması' veya 'bağımsızlı̆̆ı' değil, onların 'mevcut olmasının, hayatiyetini sürdürmesinin' anlaşılması gerektiği anlaşılmaktadır.

Bilge Kagan, KT K1'de karluk bodun erür barur erkli yagı boltı ve BK D29'da karluk bodun bunsuz erür barur erkli yagı boltı derken barur erür ikilemesiyle yukarıda sıraladığımız gerekçelere dayanarak Karluk boyunun mevcudiyetine dikkat çekmiştir. İki cümle arasındaki tek fark BK'de ikilemenin buysuz 'sıkıntısız' ile nitelenmesidir. KT yazıtında yazıcı veya taşa kazıyan kişi acaba buysuz kelimesini taşa geçirmeyi unuttu mu şeklinde bir soru akla gelebilir. Bu ihtimalin mümkün olduğu söylenebilir, ama buysuz olmadan da cümle anlamlı olabilmektedir. Bu nedenle, kelimenin kesinlikle unutulduğu söylenemez. Netice olarak KT K1'deki 


\section{J(G)}

cümle "Karluk halkı mevcudiyetini sürdürürken düşman oldu" ve BK D29'daki cümle de "Karluk halkı huzur içinde mevcudiyetini sürdürürken düşman oldu" şeklinde anlaşılmalıdır. BK yazıtındaki cümlede geçen buysuz kelimesini, CLAUsON (1972: 351b) ve onu takip edenlerin düşündüğü gibi 'dertsiz, kaygısız’ şeklinde anlamlandırılması cümlenin anlamını net olarak yansıtmaz. Cümledeki buysuz (< buy+suz) kelimesi bence hem BK D29'da hem de BK K14'te benzer anlamda kullanılmıştır. BK K14'teki buysuz bolt(a)çı sen cümlesinde buysuz 'huzur içinde, muhtaç olmayan, müreffeh' gibi bir anlamda olmalıdır. Mesela, Rabghūzìnnin Kısasü'lEnbiyâ'sında muplug kelimesi 'muhtaç' anlamıyla birkaç yerde kullanılmıştır (Boeschoten-O'kane 2015: 666a-b). İki yazıttaki munsuz 'muhtaç olmadan' gibi bir anlamda düşünülebilir. BK K14'teki cümlenin bulunduğu kısım yazıtta epey tahrip olsa da bağlamdan anlaşıldığı kadarıyla gelecekte yaşanacak güzel şeylerden bahsedildiği anlaşılıyor. Dolayısıyla, cümlenin "Huzur içinde, muhtaç olmadan yaşayacaksın" şeklinde anlamlandırılması yanlış olmayacaktır.

Sonuç olarak, Orhun yazıtlarında dört yerde görülen er- bar-ikilemesinin 'var olmak ${ }_{2}$, hayatta olmak ${ }_{2}$, yaşamak ${ }_{2}$, mevcudiyetini sürdürmek 2 ' gibi anlamlara geldiği söylenebilir.

\section{Kısaltmalar}

$\mathrm{BK}=$ Bilge Kagan yazit1.

$\mathrm{D}=$ doğu .

dip. $=$ dipnot.

DS = Derleme Sözlüğü (1993).

$\mathrm{K}=$ kuzey.

krş. = karşılaştırınız.

KT = Köl Tigin yazıtı.

$\mathrm{T}=$ Tuńukuk yazıtı.

TS = Tarama Sözlüğ̈̈ (1996).

vs. = vesaire 


\section{$J(\Theta)$}

\section{Kaynakça}

Abdurahmonov, G. \& A. Rustamov (1982). Kadimgi Turkiy Til, Taşkent: Ukituvçi Naşriyeti.

AgyagÁsi, K. (2019). Chuvash Historical Phonetics, an Areal Linguistic Study, with an Appendix on the Role of Proto-Mari in the History of Chuvash Vocalism, Wiesbaden: Harrassowitz Verlag.

Alyılmaz, C. (2005). Orhun Yazıtlarının Bugünkü Durumu, Ankara: Kurmay Yayınlar1.

Amanjolov, A. S. (2003). İstoriya i Teoriya Drevnetyurkskogo Pis'ma, Almatı: Mektep.

ARAT, R. R. (1947). Kutadgu Bilig I: Metin, İstanbul: Millî Eğitim Basımevi.

ARAT, R. R. (1979). Kutadgu Bilig III: İndeks, İndeksi Neşre Hazırlayanlar: K. ERASLAN et al. İstanbul: Türk Kültürünü Araştırma Enstitüsü Yayınları.

AşMARIN, N. İ. (1999). Slovar' Çuvaşskogo Yazıka IX, Çeboksarı: İzdatel'stvo Russika.

AYdARov, G. (1971). Yazık Orhonskih Pamyatnikov Drevnetyurkskoy Pis'mennosti VIII Veka, Alma-Ata: Nauka.

AYDıN, E. (2017). Orhon Yazıtları (Köl Tegin, Bilge Kağan, Tonyukuk, Ongi, Küli Çor), İstanbul: Bilge Kültür Sanat.

BAnG, W. (1896). “Zu den Kök Türk-Inschriften der Mongolei”, T’oung Pao, 7/4: 325-355.

BANG, W. (1898). “Zur Erklärung der köktürkischen Inschriften”, Wiener Zeitschrift für die Kunde des Morgenlandes, 12: 34-54.

BAzILHAN, N. (2005). Kazakstan Tarihi Turalı Türki Derektemeleri II: Köne Türik Bitiktastarı Men Eskertkişteri (Orhon, Yenisey, Talas), Almatı: "Dayk-Press".

BERTA, Á. (2010). Sözlerimi İyi Dinleyin: Türk ve Uygur Runik Yazıtlarının Karşılaştırmalı Yayını, Çev. E. YıLMAZ, Ankara: Türk Dil Kurumu Yayınları.

Boeschoten, H. E. \& J. O'Kane (2015). Al-Rabghūzī: The Stories of the Prophets, Qișaș al-Anbiyā', An Eastern Turkish Version I-II, Leiden-New York-Köln: E. J. Brill.

BRockelmanN, C. (1954). Osttürkische Grammatik der islamischen Literatursprachen Mittelasiens, Leiden: E. J. Brill. 


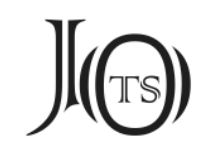

Clauson, Sir G. (1972). An Etymological Dictionary of Pre-Thirteenth Century Turkish, Oxford: Oxford University Press.

DANKoff, R. \& J. Kelly (1984). Mahmut el-Kāşгarī: Compendium of the Turkic Dialects (Dīvān Luүāt at-Türk) II, Harvard: Harvard University Press.

Doerfer, G. (1982). “Nomenverba im Türkischen”, Studia Turcologica Memoriae Alexii Bombaci Dicata, Istituto Universitario Orientale, Napoli: 101-114.

ECSEDY, I. (1980). “A Contribution to the History of Karluks in the T'ang Period”, Acta Orientalia Academiae Scientiarum Hungaricae, 34/3: 23-37.

ERCilasun, A. B. (2016). Türk Kağanlığı ve Türk Bengü Taşları, İstanbul: Dergâh Yayınları.

ERDAL, M. (1991). Old Turkic Word Formation, a Functional Approach to the Lexicon I-II, Wiesbaden: Harrassowitz Verlag.

ERDAL, M. (2004). A Grammar of Old Turkic, Leiden-Boston: Brill.

ERGiN, M. (1970). Orhun Abideleri, Ankara: Milli Eğitim Kitapları.

GENG, Shimin (2005). Gudai Tujue Wen Bei Ming Yanjiu [Eski Türk Yazıtları Araştırmalar1], Beijing: Zhongyang Minzu Daxue Chubanshe.

HAO, C. (2019). "A Study on the Chronology of Old Turkic Inscriptions", Central Asiatic Journal, 61/2: 313-321.

HAZAI, G. \& A. TIETZE (2006). Ferec ba'd eş-şidde 'Freud nach Leid' (Ein frühosmanisches Geschichtenbuch), 1. Band, Text, Berlin: Klaus Schwarz Verlag.

HovdHAUGEN, E. (1974). "The Relationship between the Two Orkhon Inscriptions", Acta Orientalia, 36: 55-82.

Inscriptions de l'Orkhon (1892). Recueillies par l'expédition Finnoise 1890, Société Finno-Ougrienne, Helsingfors: Imprimerie de la Société de Littérature Finnoise.

İsKAKov, A. I. et al. (2011). Kazak Edebi Tilinin Sözdigi XIV, Almatı: A. Baytursınulı Atındagı Til Bilimi Institutı.

KARCAUBAY, S. (2012). Orhon Muralar1: II Kitap (Tüpnüska, Okılımı, Audarmas1, Tüsiniktemesi), Almatı: Abzal-Ay Baspası.

LEssing, F. D. (1960). Mongolian-English Dictionary, Bloomington-Indiana: The Mongolia Society. 


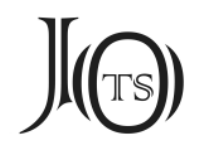

Lì, Yong-Sŏng (2008). "Orhon Yazıtları Üzerine Bazı Notlar", Türk Dilleri Araştırmaları, 18: 207-228.

MALov, S. E. (1951). Pamyatniki Drevnetyurkskoy Pis'mennosti: Tekstı i İssledovaniya, Moskva-Leningrad: İzdatel'stvo Akademii Nauk SSSR.

MARQUART, J. (1898). Die Chronologie der alttürkischen Inschriften, Leipzig: Dieterich'sche Verlags-Buchhandlung.

MAu-TsAI, L. (2006). Çin Kaynaklarına Göre Doğu Türkleri, Çev. E. KAYAoĞLU \& D. BANoĞLU, İstanbul: Selenge Yayınları.

MelioranskiY, P. M. (1899). Pamyatnik' v' Çest' Kül' Tegina, S. Petersburg: Tipografiya İmperatorskoy Akademii Nauk'.

MoRi, M. (1987). “Yenisey Yazıtlarındaki ‘Sekiz Adaklıg Barım’ Üzerine”, Erdem, 3/8: 349-356.

NADELYAYEV, V. M. et al. (1969). Drevnetyurkskiy Slovar', Leningrad: Institut Yaz1koznaniya, Akademiya Nauk SSSR.

ORKUN, H. N. (1936). Eski Türk Yazıtları I, İstanbul: Devlet Basımevi.

ÖLmEZ, M. (2012). Moğolistan'daki Eski Türk Yazıtları, Orhon-Uygur Hanlığı Dönemi: Metin-Çeviri-Sözlük, Ankara: Bilge-Su Yayıncılık.

ÖzöNDER, F. S. B. (2006). “Çöyr Yazıtı”, Modern Türklük Araştırmaları Dergisi, 3/3: 108-124.

PARlatir, İ. et al. (1998). Türkçe Sözlük I-II, 9. Baskı, Ankara: Türk Dil Kurumu Yayınları.

PeKARSKim', E. K. (1909). Slovar' Yakutskago Yazıka, Vipusk' Vtoroy (e-b), St. Petersburg: Tipografiya İmperatorskoy Akademii Nauk.

RAdLoff, W. (1893). Atlas' Drevnostoy Mongolii, Vipusk' Vtoroy, Sankpeterburg': Tipografiya İmperatorskoy Akademii Nauk'.

Radloff, W. (1895). Die alttürkischen Inschriften der Mongolei, St. Petersburg: Buchdruckerei der kaiserlichen Akademie der Wissenschaften.

RADLOFF, W. (1896). Atlas' Drevnostoy Mongolii, Vipusk' Tretiy, Sankpeterburg': Tipografiya İmperatorskoy Akademii Nauk'. 


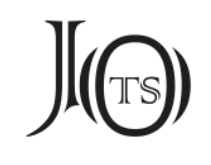

RADLOFF, W. (1897). Die alttürkischen Inschriften der Mongolei, neue Folge, nebst einer Abhandlung von W. Barthold: die historische Bedeutung der alttürkischen Inschriften, St. Petersburg: Buchdruckerei der kaiserlichen Akademie der Wissenschaften.

RADLOFF, W. (1911). Versuch eines Wörterbuches der Türk-Dialecte IV, St. Petersburg: Commissionaires de l'Académie Impériale des Sciences.

ReCEBlí, E. (2009). Qedim Türk Yazısı Abideleri, 4 Cildde, 1 Cild: Göytürk Yazısı Abideleri, I Hisse, Bakı: Nurlan.

RÓNA-TAS, A. \& B. ÁRPÁD (2011). West Old Turkic, Turkic Loanwords in Hungarian, Part I: Introduction, Lexicon «A-K», Wiesbaden: Harrassowitz Verlag.

Ross, E. D. (1930). “The Orkhon Inscriptions: Being a Translation of Professor Vilhelm Thomsen's Final Danish Rendering", Bulletin of the School of Oriental Studies, 5/4: 861-876.

RÖHRBORN, K. (2010). Uigurisches Wörterbuch, Sprachmaterial der vorislamischen türkischen Texte aus Zentralasien, Neubearbeitung, I: Verben, Band 1: ab- äzüglä-, Stuttgart: Franz Steiner Verlag.

RÖHRBORN, K. (2017). Uigurisches Wörterbuch, Sprachmaterial der vorislamischen türkischen Texte aus Zentralasien, Neubearbeitung, II: Nomina, Pronomina, Partikeln, Band 2: aš-äžük, Stuttgart: Franz Steiner Verlag.

SchwARZ, H. G. (1992). An Uyghur-English Dictionary, Washington: Western Washington.

Sidikov, S. \& K. Konkobayev (2001). Eski Türk Yazıtları (VII.-X. Asırlar), Bişkek: Kırgızistan-Türkiye Manas Üniversitesi Yayınları.

SKEAT, W. W. (1888). An Etymological Dictionary of the English Language, Oxford: At the Clarendon Press.

SoDikov, K. (2004). Kük Türk Bitiglari: Matn va Unin Tarixiy Talkini, Taşkent: Davlat Şarkşuoslik İnstituti Naşriyeti.

StARostin, S. et al. (2003). Etymological Dictionary of the Altaic Languages I-III, Leiden-Boston: Brill.

Subrakova, O. V. (2006). Hakassko-Russkiy Slovar' (Okolo 22 tis. Slov), Novosibirsk: Nauka.

Şíín, H. (2015). Kül Tigin Yazıtı, Notlar, İstanbul: Bilgi Kültür Sanat. 


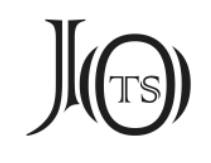

Şíín, H. (2016). Eski Türk Yazıtları Söz Varlığı İncelemesi, Ankara: Türk Dil Kurumu Yayınları.

ŞÜKÜRLÜ, A. İ. \& E. ŞÜKÜRLÜ (2001). “Göktürk Yazıtlarında Eklerin İmlâ Kuralları”, Türk Dili Araştırmaları Yıllığı Belleten 2000: 347-352.

ŞÜKÜRLÜ, E. (1993). Qedim Türk Yazılı Abidelerinin Dili, Bakı: Maarif Neşriyyatı.

TAŞAĞıL, A. (2013). Çin Kaynaklarına Göre Eski Türk Boyları (M.Ö. III-M.S. X. Asır), 2. Baskı, Ankara: Türk Tarih Kurumu Yayınları.

TEKin, Ş. (1991). “Ev Bark Nedir ?”, Tarih ve Toplum, 89: 10-13.

TEKin, T. (1968). A Grammar of Orkhon Turkic, Bloomington: Indiana University.

TEKin, T. (1988). Orhon Yazıtları, Ankara: Türk Dil Kurumu Yayınları.

TeKin, T. (2016). Orhon Türkçesi Grameri, Ankara: Türk Dil Kurumu Yayınları.

Temir, A. (1955). “Türkçe İle Moğolca Arasındaki İlgiler”, Ankara Üniversitesi Dil ve Tarih-Coğrafya Fakültesi Dergisi, 13/1-2: 1-25.

Tezcan, S. (1981). “Kutadgu Bilig Dizini Üzerine”, Türk Tarih Kurumu Belleten, 178: 23-78.

Thomsen, V. (1935). “Moğolistan'daki Türkçe Kitabeler”, Çev. R. Hulusi, Türkiyat Mecmuas1, 3: 81-119.

THomsen, V. (2002). Orhon Yazıtları Araştırmaları: [1.] Orhon ve Yenisey Yazıtlarının Çözümü İlk Bildiri; [2.] V. Thomsen Tarafından Çözülmüş Orhon Yazıtları; [3.] Yenisey Yazıtlarındaki İyi Değerlendirilmemiş Bir Harf; [4.] Turcica. Çeviren ve Yayıma Haz. V. KÖKEN, Ankara: Türk Dil Kurumu Yayınları. [ $\rightarrow$ Inscriptions de l'Orkhon déchiffrées, Imprimerie de la Société de Littérature Finnoise, Helsingfors 1896]

TIETZE, A. (2002). Tarihi ve Etimolojik Türkiye Türkçesi Lugatı I, İstanbul-Viyana: Simurg Yayınları.

TRYJARSKI, E. (1968). Dictionnaire Arméno-Kiptchak, d'après trois manuscrits des collections viennoises I: A-H, Warszawa: Państwowe Wydawnictwo Naukowe.

TuguşeVA, L. Yu. (2008). Tyurkskiye Runiçeskiye Pis'mennıye Pamyatniki iz Mongolii, Moskva: İnsan.

Türkiye'de Halk Ağzından Derleme Sözlüğü I-XII (1993). 2. Bask1, Ankara: Türk Dil Kurumu Yayınları. 


\section{$J(\Theta)$}

VAmbÉRY, H. (1899). Noten zu den alttürkischen Inschriften der Mongolei und Sibiriens, Helsingfors: Société Finno-Ougrienne.

XIII. Yüzyıldan Beri Türkiye Türkçesiyle Yazılmış Kitaplardan Toplanan Tanıklarıyla Tarama Sözlüğü I-VIII (1996). 2. Baskı, Ankara: Türk Dil Kurumu Yayınları.

YudAHIN, K. K. (1985). Kirgizsko-Russkiy Slovar' I: A-K, Frunze: Glavnaya Redaktsiya Kirgizskoy Sovyetskoy Entsiklopedii. 